California Western School of Law

CWSL Scholarly Commons

Faculty Scholarship

2018

Radical Feminist Harms on Sex Workers

I. India Thusi

California Western School of Law, ithusi@cwsl.edu

Follow this and additional works at: https://scholarlycommons.law.cwsl.edu/fs

Part of the Criminal Law Commons, Law and Gender Commons, and the Law and Race Commons

Recommended Citation

I. I. Thusi, Radical Feminist Harms on Sex Workers, 185 Lewis \& Clark L. Rev. 22 (2018).

Available at: https://scholarlycommons.law.cwsl.edu/fs/242

This Article is brought to you for free and open access by CWSL Scholarly Commons. It has been accepted for inclusion in Faculty Scholarship by an authorized administrator of CWSL Scholarly Commons. For more information, please contact alm@cwsl.edu. 


\title{
RADICAL FEMINIST HARMS ON SEX WORKERS
}

\author{
by \\ I. India Thusi*
}

Sex work has long been a site for contesting womanhood, sexuality, race, and patriarchy. Its very existence forces us to examine how we think about two very dirty subjects-money and sex. The radical feminist literature highlights the problems with sex work and often describes it as a form of "human trafficking" and violence against women. This influential philosophy underlies much of the work in human trafficking courts, was evident in a letter signed by several Hollywood starlets in opposition to Amnesty International's support for decriminalization, and is the premise of several movies and documentaries about "sex slavery." Radical feminists aim to abolish sex work but argue that only sex work purchasers should be criminalized for engaging in it. They are concerned with the structural harms of sex work and have formed alliances with groups that oppose sex work due to moralistic reasons. Like radical feminism, this Article considers the structural harms of sex work in assessing whether it should be criminalized.

However, this Article arrives at a very different conclusion and challenges the radical feminist approach to sex work, arguing that the harms of any form of criminalization, particularly to individuals with intersectional identities, are overlooked in much of the radical feminist literature on sex work. This Article incorporates empirical research from nearly two years of ethnographic fieldwork in Johannesburg, South Africa, to illus-

- Assistant Professor of Law, California Western School of Law. I gratefully acknowledge funding from the Andrew Mellon Humanities and Social Science Research Council African Scholars Program. I am grateful to Cathi Albertyn and Julia Hornberger. For generous feedback and helpful suggestions, I thank I. Bennett Capers, Jessica Clarke, Edward De Barbieri, Cynthia Godsoe, Phyllis Goldfarb, Andrea Freeman, Jing Geng, Neha Jain, Joan Howarth, Ramona Lampley, Eboni Nelson, Catherine Powell, and Sarah Rogerson. I also thank Cathi Albertyn and Julia Hornberger for consistent support and insight. This work benefitted from discussions at Albany Law School, California Western School of Law, Howard Law School, Oxford University, Temple University School of Law, and the University of Wisconsin School of Law. I am especially grateful for generative commentary and support from participants in the Law \& Society Annual Conference Feminist Legal Scholarship Panel, the Southeastern and for the editorial expertise of the staff of the Lewis \& Clark Law Review, especially Joe Langerman and Elizabeth Schmitt. Most of all, I am grateful to the young Baltimoreans who shared their stories with us, whose lives are the reason that getting police reform right is so important. 
trate the ways that criminalizing any aspect of the sex work transaction, including the demand-side, is problematic. By recognizing that some sex workers face the effects of multiple systems of oppression and that the criminal justice system has often been a source of oppression for these individuals, this Article argues that decriminalization should be the favored approach for those interested in improving the lives of sex workers. Moreover, the essentialist framing of the harms of sex work in the radical feminist literature is itself a reproduction of patriarchy and white supremacy, silencing the voices and experiences of sex workers themselves.

INTRODUCTION

I. Research in South Africa.................................................. 190

II. The Radical Feminist Structural Harms ................................... 193

III. Harms from Partial Criminalization ........................................ 199

A. Shifting Modes of Policing: The Szedish Model in Action ............ 201

B. The Arrest ......................................................................... 206

C. A Consequentialist Analysis of Partial Criminalization .............. 211

IV. Sex Work as Managed Risk ..................................................... 212

A. Freedom from Punishment Means Freedom to Resist................... 218

V. Recommendations............................................................. 225

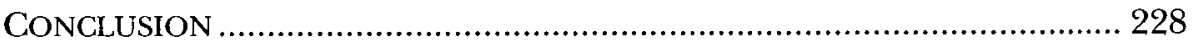

\section{INTRODUCTION}

The feminist legal scholarship on the criminalization of sex work has been divisive, leading some scholars to take a break from feminism ${ }^{1}$ and others to rely upon rhetoric and inflammation over legal reasoning or empirical analysis. ' The criminal law has been the site for these largely philosophical debates about whether women ${ }^{3}$ should be able to sell their

1 Janet Halley, Split Decisions: How and Why to Take a Break From Feminism 8-9 (2006) (highlighting the importance of taking a "break" from feminist theory to develop alternative insights into power relations and social theory).

2 Ronald Weitzer has criticized the methodology of the radical feminist approach to sex work:

Violating the canons of scientific inquiry, the radical feminist literature on prostitution and other types of sex work is filled with "sloppy definitions, unsupported assertions, and outlandish claims" such writers select the "worst available examples" of sex work and treat them as representative. Anecdotes are generalized and presented as conclusive evidence, sampling is selective, and counterevidence is routinely ignored. Such research cannot help but produce questionable findings and spurious conclusions.

Ronald Weitzer, New Directions in Research on Prostitution, 43 CRIM. L. \& SOC. CHANGe 211, 214 (2005) (internal citations omitted).

${ }^{3}$ I deliberately use the feminine to refer to sex workers throughout this Article because advocates of the radical feminist approach are primarily concerned with the violence of patriarchy in sex work and its ability to strip women of meaningful choic- 
bodies and how we should think about subordination, ${ }^{4}$ patriarchy, ${ }^{5}$ and coercion. ${ }^{6}$ All the while, sex work is treated like an unchanging object that hurts, or empowers, a singular womankind. ${ }^{7}$ This Article embraces radical feminism's consideration of structural harms and domination, but nevertheless argues that the essentialist framing of the harms of sex work in the radical feminist literature is itself a reproduction of patriarchy and white supremacy. Radical feminism fails to account for the experiences of sex workers' intersectional identities by essentializing sex work, elevating and strengthening the criminal law as a tool to address these so-called harms, and silencing the voices of sex workers themselves. In the era of mass incarceration in the United States and discriminatory policing of foreign women in South Africa, women of color are keenly aware of the

es. Accordingly, I am primarily referring to the cis "female" sex worker in this piece, although I acknowledge that there is a sizeable community of male and transgender sex workers in South Africa.

${ }^{4}$ Melissa Farley, Prostitution, Trafficking, and Cultural Amnesia: What We Must Not Know in Order to Keep the Business of Sexual Exploitation Running Smoothly, 18 YALE J. L. \& FEMINISM 109, 111 (2006) ("Prostitution/trafficking/pornography thus systematically discriminate against women, against the young, against the poor and against ethnically subordinated groups. When prostitution is conceptually morphed into sex work, brutal exploitation by pimps becomes an employer-employee relationship. When prostitution is defined as labor, the predatory, pedophiliac purchase of a human being by a john becomes a banal business transaction.").

s See generally Christine Overall, What's Wrong with Prostitution? Evaluating Sex Work, 17 SignS: J. OF WOMEN IN CULTURE AND SOC'y. 705, 724 (1992).

${ }^{6}$ Catharine A. MacKinnon, Rape Redefined, 10 Harv. L. \& POL'Y REv. 431, 448 (2016) (suggesting sex work is coercive while making several empirical claims about the nature of sex work).

In fact, women are disproportionately bought and sold in prostitution by men as a cornerstone of combined economic, racial, age-based, and gendered inequality, in which money functions as a form of force in sex because the women are not permitted to survive any other way. And the pimps and traffickers keep the lion's share of the earnings. That prostituted women were typically sexually abused in childhood previously, and most enter the sex industry as children, where they are frequently deemed by law as voluntarily engaging in crime, and then are arrested so they have a criminal record and cannot get a real job, underlines the layers of inequality involved in this technically consensual sexual activity. Thus is prostituted sex, the most multiply coerced sex on the planet, cherished as the ultimate example of consensual sex.

Id. Compare with Ine Vanwesenbeeck, Another Decade of Social Scientific Work on Sex Work: A Review of Research 1990-2000, 12 ANN. REv. SEX RES. 242, 244-45 (2001) (survey of empirical research on sex work finding that empirical "evidence began to accumulate that, in particular, the role of recruitment of force by pimps, and the role of drug use as stepping stones toward a prostitution career, were much less important than was often expected").

7 See Julia O'Connell Davidson, The Rights and Wrongs of Prostitution, 17 HyPATIA 84, 92 (2002) (noting that the radical feminist position essentializes women and takes an "over-optimistic view of women"). 
risks of criminalization and policing, and the criminal justice system should rarely be viewed as a sword for improving their lives.

As Bernard Harcourt has argued, these debates are largely about harm and whether the harms of sex work should be subservient to individualistic interests. ${ }^{8}$ Harcourt argues that such debates have collapsed the practical significance of the harm principle by being overly inclusive and reducing debates about (de)criminalization to debates over who can prove the most harms. ${ }^{9}$ While the use of escalating harms may be inconsistent with the original intent ${ }^{10}$ of the harm principle as a limiting doctrine, the consideration of social harms is entirely consistent with the utilitarian ethos of assessing the common good, " or what has been described as wealth maximization. ${ }^{12}$ Further, it is consistent with a policy approach that is sensitive to the public health literature, which frequently focuses on "harm reduction." While harm is no longer a limiting principle, it

${ }^{8}$ See Bernard E. Harcourt, The Collapse of the Harm Principle, 90 J. CRIM. L. \& Criminology 109, 149 (1999).

${ }^{9}$ Id. at 113.

${ }^{10}$ Id. at 115 ("[T] he harm principle no longer acts today as a limiting principle with regard to the legal enforcement of morality.").

1] See Part III infra, describing the utilitarian approach to criminal justice.

12 Richard Posner has advanced a brand of utilitarianism that is "constrained" and that focuses on maximizing wealth. Richard A. Posner, Wealth Maximization. Rerisited, 2 Notre Dame J. L. EThics \& PUb. Pol'y 85 (1985). This approach has been criticized and opponents of utilitarian approaches criticize its ability to suppress the rights of the individual in support of the collective. In its most pure form, this may be problematic. Anthony T. Kronman, Wealth Maximization as a Normative Principle, $9 \mathrm{~J}$. LEGAL STUD. 227, 227-29 (1980).

${ }^{13}$ G. Alan Marlatt describes the European roots of the "harm reduction" model, which relies on pragmatism:

Harm reduction, with its philosophical roots in pragmatism and its compatibility with a public health approach, offers a practical alternative to either the moral or disease models. Unlike proponents of the moral model, who view drug use as bad or illegal and who advocate supply reduction (via prohibition and punishment), harm reduction shifts the focus away from drug use itself to the consequences or effects of addictive behavior. Such effects are evaluated primarily in terms of whether they are harmful or helpful to the drug user and to the larger society, and not on the basis of whether the behavior itself is considered morally right or wrong. Unlike supporters of the disease model, who view addiction as a biological/genetic pathology and promote demand reduction as the primary goal of prevention and abstinence as the only acceptable goal of treatment, harm reduction offers a wide range of policies and procedures designed to reduce the harmful consequences of addictive behavior.

G. Alan Marlatt, Harm Reduction: Come as You Are, 21 AdDictrve BeHAV. 779, 785 (1996). The harm reduction model is consistent with consequentialism in its focus on the actual consequences of conduct rather than perceive morality. See, e.g., Monica Rao Biradavolu et al., Can Sex Workers Regulate Police? Learning from an HIV Prevention Project for Sex Workers in Southerm India, 68 Soc. SCI. \& MED. 1541 (2009) (analyzing how female sex worker organizing can reform police practices in southern India). But see I. India Geronimo Thusi, Policing Sex: The Colonial, Apartheid, and New Democracy Polic- 
may be a starting point for determining whether a law is beneficial to society, particularly when evaluating so-called "vices," which are often described as victimless crimes.

Accordingly, this Article adopts a consequentialist approach for evaluating whether the criminalization of sex work is justified and argues that the harms of criminalization outweigh the structural harms of sex work, as described in the radical feminist literature ${ }^{14}$ Consequentialism is concerned with maximizing social welfare and improving general happiness based on the actual consequences of sex work, and supports criminalization where it is best for general happiness. ${ }^{15}$ Adopting this framework, this Article considers whether criminalization is justified, and focuses on the effects of punishment on female sex workers because radical feminism is presumably interested in protecting the interests of women in the sex trade. ${ }^{16}$ In weighing the harms of criminalization, my ethnographic research in South Africa demonstrates how the literature often ignores the "harm" of criminalization and limited economic opportunities.

While this Article relies on data from South Africa, it provides insights about how we should think about sex work, particularly insofar as women of color are involved, in the United States. Part I of this Article provides background on my research in South Africa and describes the research methodology. In Part II, this Article describes the arguments of the radical feminist literature concerning sex work and argues that its essentialization reproduces harms that are inherent in white supremacy and patriarchy. Part III of this Article argues that there should be a presumption against criminalization. Part IV of this Article adopts an intersectional lens to demonstrate how the harms of criminalization outweigh the harms of sex work itself, as illustrated by my research in South Africa. Part $\mathrm{V}$ of this Article recommends the adoption of a managed risks approach to assess whether the criminalization of sex work produces more harms than good in a particular locale, and to ensure the adoption of a local response that reduces the potential for the marginalization of sex workers.

ing of Sex Work in South Africa, 38 FoRDHAM INT'L L.J. 205 (2015) (noting the risks of reducing sex workers to carriers of contagion and regulating their bodies in the name of "public health").

${ }^{14}$ Joshua Greene \& Jonathan Cohen, For the Law, Neuroscience Changes Nothing and Everything, 359 PHILOs. Trans. R. Soc. LOND. B. 1775, 1775 (2004) (describing the "consequentialist justification for state punishment, according to which punishment is merely an instrument for promoting future social welfare").

${ }^{15} I d$. at 1776. ("According to the forward-looking, consequentialist theory... punishment is justified by its future beneficial effects." (citation omitted)).

16 See supra, note 6. 


\section{RESEARCH IN SOUTH AFRICA}

My analysis incorporates the findings from my legal ethnography on the policing of sex workers in Johannesburg, South Africa. During the course of my research, I adopted several research methods to allow for a multi-faceted analysis of the policing of sex work. These methods included participant observation, 56 semi-structured interviews, mapping of the policing of sex work, and focus group discussions. I spent nearly two years amongst sex workers and police to understand the perceptions, values, behaviors, and norms that govern the relationship between sex workers and police. "To make law a more effective instrument of policy, the argument runs, it is necessary to understand why it develops, what forms it takes, and especially what are its consequences." ${ }^{\prime 7}$ This empirical research provides the context for my arguments regarding the treatment of sex work in the criminal law and feminist legal contexts. It provides insights that complicate how we should think and talk about sex work. While the empirical work was done in South Africa, it provides insights about how sex work is expressed that are relevant in the United States. Moreover, much of the radical feminist research on sex work exploits the South African context. ${ }^{18}$

An ethnographic approach is particularly useful in obtaining a greater understanding of how the criminal law treats sex work because culture plays such a significant role in how sex work is conceived. Police members, criminal justice actors, and scholars often incorporate their personal moral and cultural values into how they treat sex work. ${ }^{19}$ Understanding how and whether these values influence sex work, a research objective subject to value-based judgments and cultural marginalization, is significant. "If culture is to mean 'deep level assumptions,' then it cannot be read off structural arrangements or quantifications of . . . attitudes. Instead, researchers need to take an ethnographic approach, whereby they prioritize the social actor and his/her subjective orientation ...." Ethnography allows the researcher to explore how subjective values influence sex work by allowing the researcher to participate in and observe the everyday occurrences that form sex work. ${ }^{21}$ Ethnography provides da-

${ }^{17}$ Richard D. Schwartz, Field Experimentation in Sociolegal Research, 13 J. LEGAL EDUC. 401, 401 (1961).

${ }^{18}$ See Melissa Farley et al., Prostitution in Five Countries: Violence and Post-Traumatic Stress Disorder, 8 FeminISM \& Psychology 405 (1998); Catharine A. MacKinnon, Trafficking, Prostitution, and Inequality, 46 HARV. C.R.-C.L. L. REV. 271, 291 (2011).

${ }_{10}$ Monique Marks, Researching Police Transformation: The Ethnographic Imperative, 44 BRIT. J. CRIMINOLOGY 866, 870 (2004).

${ }^{20} I d$.

${ }^{21}$ D. SOYini Madison, Critical EthnOgRapir: Method, Ethics, AND PERFORMANCE 25-26 (2011) (discussing the role of ethnography in challenging the role of "objective" inquiry and in questioning subjectivity as well). 
ta for the actuality of sex work and allows the researcher to observe the inconsistencies between practice and policy. ${ }^{22}$

Ethnography studies the natural setting of the research object and interprets the subjective interactions that occur within it. ${ }^{23}$ My principal ethnographic data collection method was participant observation. Participant observation is a method for collecting data that requires the researcher to both actively participate in and observe the natural environment of the research subjects. ${ }^{24}$ Although time consuming and not always specific to the research aim, participant observation is critical in revealing the distinctions between expressed conduct and actual conduct. ${ }^{25}$ It is capable of exposing biases, routine behavior, and understandings that research participants would rather not explicitly express. It requires more than sitting back and watching. ${ }^{26}$ It requires that the researcher actively participate in the conduct of the informants, observe both the spoken and unspoken conduct and circumstances of informants, and continuously engage in data collection through extensive field notes. ${ }^{27}$ Because law is socially situated, these observations provide insight into how law is lived and expressed.

I engaged in participant observation for this research project by joining police members during their routine patrols of sex workers. I came to appreciate the exhaustion police members experience during 12-hour shifts that stretch between 6:00 p.m. and 6:00 a.m. ${ }^{28}$ I also spent significant time within the police stations to contextualize the policing of sex workers within the larger policing task. Although I did not literally participate in policing by responding to community complaints or carrying a

22 Martyn Hammersley \& PAUl AtKInson, Ethnography: PrinCiPLes in Practice 2 (2007) ("The ethnographer participates, overtly or covertly, in people's daily lives for an extended period of time, watching what happens, listening to what is said, asking questions; in fact collecting whatever data are available to throw lights on the issues which he or she is concerned.").

23 H.F. WOlcott, ETHNOGRAPHY: A WAY OF SEEING 46 (1999).

${ }^{24}$ Danny L. Jorgensen, Participant Observation, in EMERGing Trends IN THE SOCIAL AND BEHAVIORAL SCIENCES 1 (Robert A. Scott \& Stephen M. Kosslyn eds., 2015) ("Participant observation is a unique method for investigating human existence whereby the researcher more or less actively participates with people in commonplace situations and everyday life settings while observing and otherwise collecting information.").

${ }^{25}$ See Barbara Tedlock, From Participant Observation to the Observation of Participation: The Emergence of Narrative Ethnography, $47 \mathrm{~J}$. OF ANTHROPOLOGICAL REs. 69, 70 (1991).

${ }^{26} I d$. at 78 .

${ }^{27} I d$. at 83 .

${ }_{28}$ See Julia Hornberger, Human Rights and Policing: Exigency or Incongruence?, 6 ANN. REV. L. \& SOC. SCI. 259, 261-62 (2010) (providing a brief summary of the history of policing studies in sociology and anthropology and the role of participant observation). 
firearm, I did accompany police members during routine patrols to respond to complaints and during traffic stops. I attempted to maintain as much proximity to the policing task as legally permissible. I conducted participant observation with sex workers by adopting the role of a friendly patron, spending significant time at sex work hot spots, ${ }^{29}$ drinking at sex work venues, socializing with sex workers, and living near a sex work hot spot.

I conducted semi-structured interviews with 36 sex workers and 25 police members regarding the relationship between police and sex workers. The sample is relatively small, but as Sandelowski has argued, "qualitative analysis is generically about maximizing understanding of the one in all of its diversity; it is case-oriented, not variable-oriented." ${ }^{30}$ Accordingly, smaller samples are typical of qualitative research, which is concerned with depth and rich description. "An adequate sample size in qualitative research is one that permits-by virtue of not being too large-the deep, case-oriented analysis that is a hallmark of all qualitative inquiry, and that results in-by virtue of not being too small-a new and richly textured understanding of experience. ${ }^{31}$ Qualitative research is concerned with achieving depth and providing description and need not be generalizable. ${ }^{32}$

This research adopts an epistemological approach consistent with subtle realism, which is "a marker of an approach to social research that takes the view that, although we always perceive the world from a particular viewpoint, the world acts back on us to constrain the points of view that are possible. ${ }^{, 33}$ It recognizes the subjectivity of the research process and views research as studying "transitive objects." ${ }^{34}$ Throughout this Article, I incorporate my personal experiences with the research object and comment on how perceptions of my personal identity shaped the research object, reflecting a conscious choice to interfuse reflexivity within the text. Reflexivity is a method for understanding how the "historical, socially constructed reality in a partial, provisional sense through an intensive, experimental encounter with people who live by these cultural constructions of reality." ${ }^{35}$ This approach recognizes the multiple subjectivities that may occur during the research process and rejects a method-

${ }^{29}$ In the context of this Article, sex work hot spots are locations where sex work transactions regularly occur.

${ }^{30}$ Margarete Sandelowski, Focus on Qualitative Methods: Sample Size in Qualitative Research, 18 REs. NURSING \& HEALTH 179, 180 (1995) (internal citations omitted).

${ }^{31} I d$. at 183.

${ }^{32} I d$.

${ }^{33}$ Clive Seale, Quality in Qualitative Research, 5 QUALITATrve INQUIRY 465, 470 (1999).

${ }^{34}$ Id.

${ }^{35}$ Douglas E. Foley, Critical Ethnography: The Reflexive Turn, 15 INT'L J. QUALTTATIVE STUd. IN EDUC. 469, 472-73 (2002). 
ology premised on singular objectivity. ${ }^{36}$ However, it also recognizes that the rubric of experiences possible during research is limited by the environment and the nature of the research object. Thus, this study recognizes my unique positionality in relation to the research participants, the shifting temporalities while studying the research object, and the subjectivities in interpreting how the urban landscape is mapped.

During the course of the ethnography, my perspective on the policing of sex work was constantly evolving and subject to the variables of passing time, seasonal and political changes, geography, and the observation of religious holidays. There was no singular "policing of sex workers." The policing of sex workers largely occupies a space on the margins of law, sometimes within the law and sometimes outside of it. This is a space where rules are constantly re-negotiated to satisfy the needs of the moment. ${ }^{37}$ Much of the feminist debate around sex work has focused on the sex worker and issues of consent, coercion, subordination, freedom, and sexual autonomy. Some of these debates proceed as if sex work were static. There often is a blanket recommendation for decriminalization or partial criminalization without much discussion about how these legal approaches would actually look on the ground.$^{38}$ Much of the debate tends to be circular because it often avoids the most direct question: how do we, as feminists, want to think about sex? This Article provides an empirical basis for examining the structural harms of the criminalization of sex work and now addresses the question of whether the criminalization of sex work is justified.

\section{THE RADICAL FEMINIST STRUCTURAL HARMS}

There are generally four approaches to the criminalization of sex work, including: (1) total criminalization, (2) partial criminalization with the goal of eventual elimination of sex work, (3) decriminalization with regulation, and (4) total decriminalization. ${ }^{39}$ Sex work is currently regulated pursuant to the first approach and is criminal for both the sex

${ }^{36}$ See Dolores Delgado Bernal, Critical Race Theory, Latino Critical Theory, and Critical Raced-Gendered Epistemologies: Recognizing Students of Color as Holders and Creators of Knowledge, 8 QUALTATIVE INQUIRY 105, 111, 113, 115 (2002) (discussing the debates around objectivity and subjectivity as they relate to the methods adopted by critical race theorists).

${ }^{37}$ See Part IV infra, describing changes in the policing of sex work over time.

38 See Sylvia A. Law, Commercial Sex: Beyond Decriminalization, 73 S. CAL. L. REv. 523 (2000) (arguing that feminists should move beyond the issues of decriminalization to develop a theory about how the regulation of sex work should look on the ground to reduce the harms associated with it).

${ }^{39}$ Janet Halley et al, From the International to the Local in Feminist Legal Responses to Rape, Prostitution/Sex Work, and Sex Trafficking: Four Studies in Contemporary Governance Feminism, 29 HARV. J. L. \& GENDER 335, 338-39 (2006). 
worker and sex work client in the United States ${ }^{10}$ and South Africa. ${ }^{41}$ Partial criminalization relates to the so-called "Swedish model,"42 which prohibits the conduct of the sex work client but does not criminalize the conduct of the sex worker. Radical feminists generally support this approach because it theoretically protects the sex worker, who is a victim of her ${ }^{43}$ occupation, while criminalizing the client in the hopes of eliminating future demand for sex work. Legalization, or regulation, pertains to the decriminalization of sex work for both the client and sex worker although it allows for additional laws and/or ordinances aimed at regulating aspects of the sex work trade, e.g., zoning ordinances specific to brothels. ${ }^{44}$ Finally, decriminalization is the total elimination of all criminal sanctions relating to sex work. ${ }^{45}$ Under decriminalization, sex work would be treated like any other occupation, and would be subject to the general laws. ${ }^{46}$

The theoretical underpinnings for the various legal outcomes generally rely upon principles advanced in a continuum from moralism, radical feminism, to liberal theory. Western-based radical feminism is often in conversation with liberal feminism and its ideas of individual choice and sex work as work. Radical feminists have argued that sex should never be

${ }^{40}$ But see NEV. REV. STAT. $\S 201.354$ (2017), making prostitution based in brothels legal in Nevada:

1. It is unlawful for any person to engage in prostitution or solicitation therefor, except in a licensed house of prostitution.

2. Except as otherwise provided in subsection 3, a person who violates subsection 1 is guilty of a misdemeanor.

3. A person who violates subsection 1 by soliciting a child for prostitution:

(a) For a first offense, is guilty of a category $\mathbf{E}$ felony and shall be punished as provided in NRS 193.130 , and by a fine of not more than $\$ 5,000$.

(b) For a second offense, is guilty of a category $\mathrm{D}$ felony and shall be punished.

Id. See also Barbara G. Brents \& Kathryn Hausbeck, Violence and Legalized Brothel Prostitution in Nevada: Examining Safety, Risk, and Prostitution Policy, $20 \mathrm{~J}$. OF INTERPERSONAL VIOLENCE 270, 271 (2005) (finding that legalization of sex work in Nevada decreases harms).

${ }^{41}$ Sexual Offences Act 23 of $1957 \S 10$ BSRSA (updated through 2014) (S. Afr.).

${ }^{42}$ The Swedish model has also been labeled as the abolitionist approach to sex work, and partial decriminalization. See Halley, supra note 39, at 338; see also Janie A. Chuang, Rescuing Trafficking from Ideological Capture: Prostitution Reform and. Antitrafficking Law and Policy, 158 U. PA. L. REv. 1655, 1666-68 (2010) (outlining the conflation of prostitution and sex trafficking to advance an abolitionist and carceral approach to feminism).

${ }^{43}$ I deliberately use the feminine word her because advocates of this approach are primarily concerned with the violence of patriarchy in sex work and its ability to strip women of meaningful choices.

44 See Halley, supra note 39, at 338-39.

${ }^{43} I d$.

${ }^{46}$ Prabha Kotiswaran, Bom unto Brothels-Toward a Legal Ethnography of Sex Work in an Indian Red-Light Area, 33 L. \& SOC. INQUIRY 579, 588 (2008). 
a tool to address economic struggles. ${ }^{47}$ Scott Anderson argues, "Prohibition [of sex work] not only denies individuals the choice to sell sex for money, it also signals that no one should be expected to make choices about sex just to escape economic hardship." ${ }^{, 48}$ Feminists generally agree that sex workers should never be criminalized for engaging in sex work. ${ }^{49}$ However, feminists disagree as to whether sex should ever be viewed as viable work. Radical feminists argue that abolition is the ultimate goal because sex should never be an employment option. ${ }^{50}$ sition:

Jody Freeman provides an honest account of the radical feminist po-

Conceiving of sexuality in market terms dehumanizes how we think and act about something extremely important to our conception of self. It would reduce sexuality to just another fungible good because commodification leads to "the domino effect"-the tendency in our society to completely commodify in all respects and for all purposes that which is commodified at all. ${ }^{51}$

Freeman boldly claims that "we need to reclaim values that affirm and enhance, not demean human beings. Feminism that is unwilling or unable to choose amongst an assortment of behaviors may be tolerant, but to me it is apathetic and apolitical. ${ }^{52}$ But the declaration begets the question, whose values set the base level for the norms?

Carole Pateman argues that women who sell sex are selling themselves and thus their womanhood. ${ }^{53}$ Pateman claims that the social conditions of prostitution are such that, inherently, the women are subordinated. ${ }^{54}$ Christine Overall similarly claims that women are subordinated in prostitution ${ }^{55}$ and Debra Satz argues that although sex work is not inherently wrong, it is wrong to the extent that it influences men's perceptions of women. ${ }^{56}$ Central to the debate is the issue of autonomy: "Radical feminists say that prostitution is not a harmless, 'private' transaction but a

47 Overall, supra note 5, at 709.

${ }^{48}$ Scott A. Anderson, Prostitution and Sexual Autonomy: Making Sense of the Prohibition of Prostitution, 112 ETHICS 748, 777 (2002).

49 Halley, supra note 39, at 411 ("[A]ll feminists are in agreement that sex workers should not be penalized for doing sex work.").

${ }^{\text {so }}$ Chuang, supra note 42, at 1664 .

${ }^{51}$ See Jody Freeman, The Feminist Debate over Prostitution Reform: Prostitutes' Rights Groups, Radical Feminists, and the (Im)possibility of Consent, 5 BERKELEY WOMEN'S L. J. 75, $102(1990)$.

${ }^{32} I d$. at 105.

33 Carole Pateman, The Sexual Contract 205 (1988); Kari Kesler, Is a Feminist Stance in Support of Prostitution Possible? An Exploration of Current Trends, 5 SEXUALITIES 219, 224 (2002).

${ }_{54}$ Pateman, supra note 53, at 2.

${ }_{55}$ See Overall, supra note 5, at 723.

${ }_{56}$ Debra Satz, Markets in Women's Sexual Labor, 106 ETHICs 63, 78-79 (1995). 
powerful means of creating, reinforcing, and perpetuating the objectification of women through sexuality."

Scott Anderson resists the liberal treatment of sex work as another form of labor and argues that it reduces female sexual autonomy. ${ }^{58} \mathrm{He}$ claims:

[A] person's sexuality almost always figures prominently as an aspect of his or her self-conception, status in society, and economic and social prospects. ... It is because sex plays such a pivotal role in the lives of most adults ... that it creates its own special ... realm within which one can be more or less autonomous.

In this way, he argues that sex work reduces sexual autonomy. ${ }^{60}$ Radical feminists can be said to implicitly subscribe to the theory of asymmetry: "Those who hold the asymmetry thesis believe that markets in reproduction and sex are asymmetric to other labor markets." ${ }^{61}$ They believe that sex markets cannot be compared to other markets because there is an asymmetry between the contracting parties in a sex work relationship. In general, sex is essentialized and universalized in this worldview. " $[\mathrm{I}] \mathrm{n}$ hegemonic Euro-American culture, sexuality and money are thought of as things that cannot, do not, and/or should not mix."

In addition to this essentialization of sex, Catharine MacKinnon and other radical feminists argue that sex work is a form of violence against women, and that sex workers cannot exhibit agency in a system of male subordination of women. ${ }^{64}$ Andrea Dworkin reduced sex work to the male experience: "In the male system, women are sex; sex is the whore... . Using her is using pornography. ... Being her is being pornography." Dworkin views sex work as a per se violation on the woman and as an act of violence against women. ${ }^{66}$ This perspective suggests that those who engage in all forms of sex work are victims of patriarchy based on the sexual objectification of women. Judith Vega argues that

${ }^{57}$ Freeman, supra note 51, at 92.

${ }^{5}$ See Anderson, supra note 48 , at 777 .

59. at $774-75$.

Id. at 777 .

${ }^{31}$ Satz, supra note 56 , at 63 .

${ }^{62}$ Noah D. Zatz, Sex Work/Sex Act: Law, Labor, and Desire in Constructions of Prostitution, 22 SIGNS: J. OF WOMEN IN CULTURE \& SOC'Y 277, 288 (1997).

63 . at 294.

o4 See generally Catharine A. MacKinnon, Prostitution and Civil Rights, $1 \mathrm{MICH}$. J. GeNDER \& L. 13 (1993).

6: Zatz, supra note 62, at 292 (quoting ANDREA DWORKN, PORNOGRAPHY: MEN POSSESSING WOMEN (1989)).

if $S e e$, e.g., ANDrEa DWORkIn \& Catharine A. Mackinnon, Pornography and CiviL RightS: A NEW DAY FOR WOMEN's EQUALITY (1988); Aziza Ahmed, Feminism, Power, and Sex Work in the Context of HIV/AIDS: Consequences for Women's Health, 34 HARV. J. L. \& GENDER 225, 229 (2011). 
"[f]eminist politics as well as theory have declared the incompatibility of coercion and genuine consent. It is precisely this thinking in opposites ... that paralyzes feminist thought about sexual violence." ${ }^{\circ 7}$ Much of radical feminism survives or falls entirely on the essentialization of sex and its reduction to a singular, universal experience where women are mere passersby and victims of sex.

Under the radical feminist theory, individual women's choices are given little regard or expression, and it is presumed that women cannot exercise a choice that involves the giving away of their bodies. ${ }^{68}$ This marks a deliberate deviation from traditional liberal theory. Much of "traditional liberal theory ... is committed to autonomy, individualism, and minimal state interference in private choice. Liberal theory is premised on an assumption that individuals are atomistic, pre-social beings who exist independent of their community. ${ }^{" 69}$ Radical feminism concerns itself with structural concerns and views the woman who chooses to engage in sex work as either a victim of circumstance or a victim of her own false consciousness. ${ }^{70}$ Pornography is condemned for reinforcing the masculinity and patriarchy that demotes women to the satisfiers of male sexual urges. ${ }^{71}$ Melissa Farley has declared, "Like slavery, prostitution is a lucrative form of oppression. And both slavery and prostitution are rife with every imaginable type of physical and sexual violence." ${ }^{, 2}$ She advocates for a form of radical feminism that intends to save women from the captivity of patriarchy. ${ }^{73}$

Radical feminists have captured the imaginations of many, creating a political movement to ban the scourge of sex trafficking and child prostitution. ${ }^{74}$ As Phil Hubbard notes, "conflicts between different sexualities, moralities and identities are often orchestrated by the press in a lurid and sensationalist manner to create national 'moral panics' about particular individuals and groups. ${ }^{, 75}$ Western discourses around sex trafficking

${ }^{67}$ Freeman, supra note 51, at 98.

is $I d$.

69 $I d$ at 86 .

${ }^{70}$ See, e.g., id. at 95.

7 Catharine A. MacKinnon, Sexuality, Pornography, and Method: Pleasure Under Patriarchy, 99 ЕтнпсS 314, 315 (1989).

72 Farley, supra note 4 , at 110.

78 Id. at 141-43. Farley articulates:

If we are to prevent the harms of prostitution, and if its harms are intrinsic to prostitution, just as slavery's harms are intrinsic to that institution, then we must ultimately prevent the existence of prostitution. We must learn how it is that men make the choice to buy women in prostitution ....

Id. at 143.

${ }^{74}$ See id. at 141-43; Belkys Garcia, Reimagining the Right to Commercial Sex: The Impact of Lawrence v. Texas on Prostitution Statues, 9 N.Y. CITY L. REv. 161, 163 (2005).

${ }_{75}$ Phil Hubbard, Sex Zones: Intimacy, Citizenship and Public Space, 4 SEXUALITIES 51, $53(2001)$. 
and its conflation with sex work is very much a testament to the power of moral sensationalism to regulate sexual deviants, even when it purports to protect them ${ }^{76}$ All women who have traveled afar for sex work become included in the blanket label of "sex trafficking victim." Through intense advocacy, the radical feminist movement has managed to pass several anti-prostitution bills and garner global support for a movement aimed at preventing sex trafficking, including the UN Trafficking Proto$\operatorname{col} 29^{78}$ and the 2000 US Victims of Trafficking and Violence Protection Act. ${ }^{79}$ In South Africa, there is the Prevention in the Trafficking of Person Act, 2013, which was enacted to give effect to international agreements regarding trafficking. ${ }^{80}$

As much as it purports to support subjectivity, the radical feminist position is predicated on its presumed objectivity, on its ability to proclaim universal truths about male and female sexuality. Sex is a topic infused with multiple subjectivities and alternate realities but is treated like an immovable object in some of these discussions. Popular artists have come out against decriminalization of sex work, while ironically portraying characters that are decidedly sexually liberal and have the choice to

${ }^{76}$ See generally Elizabeth Bernstein, Militarized Humanitarianism Meets Carceral Feminism: The Politics of Sex, Rights, and Freedom in Contemporary Antitrafficking Campaigns, 36 SIGNS 45 (2010) (discussing the militarization of human rights in sex trafficking campaigns); Chuang, supra note 42, at 1665.

77 Jo Doezema, Ouch!: Western Feminists' 'Wounded Attachment' to the 'Third World Prostitute,' 67 FEMINIST Rev. 16, 16 (2001). Doezema argues:

[Certain feminist groups'] construction of 'third world prostitutes' is part of a wider western feminist impulse to construct a damaged 'other' as justification for its own interventionist impulses. The central argument of this article is that the 'injured body' of the 'third world trafficking victim' in international feminist debates around trafficking in women serves as a powerful metaphor for advancing certain feminist interests, which cannot be assumed to be those of third world sex workers themselves.

Id.

${ }^{78}$ Protocol to Prevent, Suppress and Punish Trafficking in Persons, Especially Women and Children, Supplementing the United Nations Convention Against Organized Crime, $\$ \$ 2(a), 3(a)$, Nov. 15, 2000, 114 Stat. 1466, 2237 U.N.T.S. 319. One of the most influential NGOs in the negotiation of the various UN protocols, Coalition against Trafficking of Women (CATW), was founded by radical feminist Kathleen Barry.

${ }_{79}$ US Victims of Trafficking and Violence Protection Act of 2000, 22 U.S.C. $\S \S 7101-7114$ (2012). A United Nations conference in 1981 in Nice, France, issued a release stating that "all prostitution is forced prostitution." Rep. of Jean FernandLaurent (Special Rapporteur on the Suppression of the Traffic in Persons and the Exploitation of the Prostitution of Others), Activities for the Advancement of Women: Equality, Development and Peach, U.N. Doc. E/1983/7 (Mar. 17, 1983).

${ }^{80}$ Prevention and Combating of Trafficking in Persons Act 7 of $2013 \S 1.3(\mathrm{a})$ BSRSA (updated through 2014) (S. Afr.). 
frame their own sexualities. ${ }^{81}$ For some reason, these women are enlightened enough to manifest personal sexual liberation but feel the need to limit whether sex workers can do the same for themselves. But the question remains if all women are subject to male domination and oppressed by it, then how can any of us defy this domination, let alone proclaim to identify uniform parameters for it? And whose version of domination do we accept? Are we to accept that of privileged Western feminists without question because they proclaim to have a higher consciousness above their research subjects? Are they not similarly blinded by male domination and thus unable to see $(k)$ sexual liberation or provide consent?

The radical feminist body of feminist scholarship suffers from a critique that has long plagued feminism-it is part of the Western, middleclass, white female agenda that only superficially considers other experiences, particularly those of women of color or women in postcolonial societies. ${ }^{82}$ It generally lacks in its attention to intersectionality ${ }^{83}$ and the unique experiences of women who experience overlapping and intersecting forms of oppression. But, more critically, it is disconnected from classes of women who fall in this world and thus is plagued by assumptions and premises that simply do not apply in certain contexts. It identifies structural harms of sex work but fails to adopt a consequentialist approach in its advocacy for more criminalization, and thus fails to see that the structural harms from criminalization itself are in fact greater than the structural harms of sex work, as they define them.

\section{HARMS FROM PARTIAL CRIMINALIZATION}

My fieldwork shows that any form of criminalization of sex work may be harmful to sex workers, even if only the sex workers' clients are criminalized. During the course of my ethnography, ${ }^{84}$ I observed the harms

${ }^{81}$ Letter from Magdy Abdel-Hamid, Egyptian Assoc. for Cmty. Participation Enhancement, Egypt, et al,, to Salil Shetty, Sec'y Gen., Amnesty Int'l and Steven W. Hawkins, Exec. Dir., Amnesty Int'l U.S.A., (Jul. 17, 2015) (on file with Coal. Against Trafficking in Women), http://catwinternational.org/Content/Images/Article/621/ attachment.pdf.

${ }^{82}$ See K.L. Broad, Critical Borderlands $\mathcal{F}^{2}$ Interdisciplinary, Intersectional Coalitions, 78 DENV. U. L. REV. 1141, 1148 (2000) ("[T]he sociological lens by which we view the feminization of poverty is characterized both by white, middle class feminism . . and the subordination of poor women of color.").

${ }^{83}$ See, e.g., Kimberle Crenshaw, Mapping the Margins: Intersectionality, Identity Politics, and Violence Against Women of Color, 43 STAN. L. REV. 1241 (1991).

${ }^{84} \mathrm{I}$ adopted a narrative methodology in this section to illustrate how the changes that I observed over time evolved and to demonstrate the variations of police-sex worker relationships in the same locale. Narrative inquiry has been defined as:

[A] collaboration between researcher and participants, over time, in a place or series of places, and in social interaction with milieus. An inquirer enters this matrix in the midst and progresses in the same spirit, concluding the inquiry still 
that stem from an approach that is consistent with partial criminalization. ${ }^{85}$ This section provides an empirically-grounded basis ${ }^{86}$ for questioning the partial criminalization model that has been advanced in the radical feminist literature. At my research site, Rosebank, ${ }^{87}$ there was a relatively small community of sex workers and police who worked around the Oxford Road area in Johannesburg. Police were very acquainted with the sex work hot spots and would take me on patrols in these areas. The sex workers knew the names of the police officers, and police officers were familiar with the various sex workers. The relationship between sex workers and police proved to be quite dynamic and cyclical during the course of my fieldwork in Rosebank.

As the months went by, I learned that police officers negotiated informal rules with the individual sex work contractors. Sex workers were, as a general policy in the area, not arrested. The general policy of the Rosebank police was to ignore sex workers. Some officers solicited "permits" from individual sex workers new to the business, but despite this, the policy was generally one of tolerance and acceptance of sex work.

Nonetheless, both police and sex workers reported that police routinely arrested sex workers in 2011 and 2012, before I began my field-

in the midst of living and telling, reliving and retelling, the stories of the experi-

ences that made up people's lives, both individual and social.

D. Jean Clandinin, Narrative Inquiry: A Methodology for Studying Lived Experience, 27 REs. STUD. IN MUSIC EDUC. 44, 46 (2006). Using narrative as method employs the three dimensions of narrative which include "the personal and social (interaction) along one dimension; past, present and future (continuity) along a second dimension; place (situation) along a third dimension." $I d$. at 47 . This method highlights the benefits of ethnography by highlighting how the depth of time allows the researcher to observe multiple iterations of the same research object and subjects. It provides a dichotomy for understanding how place and time impact how sex work is policed. Adopting a narrative approach "highlights the relational dimension of narrative inquiry. Narrative inquirers cannot bracket themselves out of the inquiry but rather need to find ways to inquire into participants' experiences, their own experiences as well as the co-constructed experiences developed through the relational inquiry process." Id.

${ }^{85}$ See Sally Engle Merry, New Legal Realism and the Ethnography of Transnational Law, 31 L. \& SOC. INQUIRY 975, 976 (2006) (highlighting the role of ethnography in studying legal phenomena to contextualize how we understand law and human rights).

${ }^{86}$ See generally Adrienne D. David, Regulating Sex Work: Erotic Assimilationism, Erotic Exceptionalism, and the Challenge of Intimate Labor, 103 CALIF. L. REv. 1195, 1270 (2015) (noting that scholars have given "little theoretical or empirical attention to the demand side" of the sex work transaction, highlighting the value of research that provides insights to the policing of clients).

${ }^{87}$ Rosebank is located in the upper-middle-class northern suburbs in Johannesburg. The sex workers in Rosebank cater to a high-end clientele from Johannesburg's northern suburbs. The site allows for prompt and discreet transactions for individuals looking to purchase sex while their families wait for them at home. Rosebank sex workers are well aware of this and charge a premium for their services. 
work. Previously, police would request identification from sex workers and initiate deportation proceedings against sex workers who were unable to furnish identification. I was told that Rosebank police officers were charged with corruption and police brutality in connection with the policing of sex workers. This lawsuit had a chilling effect on the arrest of sex workers, and a formal policy prohibiting the arrest of sex workers was adopted. During semi-structured interviews, police officers acknowledged that measures were required to protect the human rights of sex workers and prevent their arrest. Adopting this human rights language, they claimed to have tolerated sex workers rather than arrested them or otherwise prevented them from working. After I had been in the field for several months, between August and November 2013, sex workers confirmed the police officers' accounts and repeatedly confirmed that the police were no longer policing them. Several sex workers indicated that during the prior year, the police would arrest them and harass them on a routine basis.

During this time period, the relationship between police and sex workers was quite individualistic; it really depended on the individual sex worker and the particular officer. As one sex worker informed me, police were "like anyone else. You like some and you hate others. ${ }^{88}$ Another sex worker stated, "The police are like anyone else. Some are nice, some aren't., ${ }^{, 89}$ Sex workers informed me that they felt comfortable going to the police for assistance and would often call upon certain officers, who were regular clients. One sex worker reported that police members actually went to the sex workers while they were working outside and directed them to go to the police station if they experienced any police harassment or abuse. Police members, including the head of visible policing, acknowledged the illegality of the sex workers' acts but informed me that sex work simply was "not a police priority;" rather, robberies and other serious crimes in Rosebank demanded their attention. The police could no longer devote resources to the issue of sex workers, and so the "ladies of the night" ${ }^{\text {90 }}$ were left alone.

\section{A. Shifting Modes of Policing: The Swedish Model in Action}

Up until November 2013, I had been consistently told that sex workers were no longer being harassed or arrested by the police. Nonetheless, during one of my night-time patrols, I observed an interaction between thor).

${ }^{88}$ Interview with Anonymous Sex Worker in Rosebank, S. Afr. (on file with au-

${ }^{89}$ Interview with Anonymous Sex Worker in Rosebank, S. Afr. (on file with author).

${ }^{90}$ The police officers from Rosebank frequently referred to sex workers as ladies of the night, when they are trying to be polite. In other contexts, they would simply called sex workers "prossies" as shorthand for prostitutes. 
one of my regular patrol partners, Sipho, and a sex worker that demonstrated how easily police and sex workers could end up in altercations. The corner of Oxford Road and Rudd Road near the Illovo Total gas station generally has a large population of transgender sex workers. As we drove past this corner one evening, Sipho was particularly annoyed by the sex workers and stated that they tended to be a bit disrespectful. One of the sex workers shouted profanities at Sipho, and he became visibly angry and stopped the police vehicle as if he were getting ready to jump out. But, he did not. Despite this near-confrontation, I spent my first five months in Rosebank being told that "the situation is fine," and with the exception of a few outliers, the relationship was cooperative and sex workers were comfortable going to the police for assistance.

However, following the December holiday period in 2013, the relationship between police and sex workers around Rosebank rapidly deteriorated. Sex workers informed me that the police had shifted their energies towards their clients. The police had begun to extort the clients who they found soliciting sex workers. This endeavor became so lucrative that patrolling officers would spend time at known sex work hot spots, waiting for clients to finish with sex work transactions so that they could engage in their scheme. I observed police from central Johannesburg patrolling in Rosebank and heard reports of police from Pretoria, a city one hour from Johannesburg, travelling to Rosebank in hopes of reaping huge returns from the large bribes that were being extracted from Rosebank clients. One police member recounted to me the practicalities of obtaining a client bribe:

INDIA: What is the situation in terms of dealing with the clients of the prostitutes?

KARABO: They must also arrest them because they are loitering in prostitution so they are accomplices.

INDIA: The police, you see a man who is about to pick up a prostitute, what do you do then? . .

KARABO: Yes he gets arrested.

INDIA: And then he gets detained in the police station?

KARABO: Yes.

INDIA: How often do you have to make those arrests?

KARABO: Almost every day.

INDIA: How do the clients react?

KARABO: They try to bribe the police because they don't want their family to find out. At the end of the day we end up taking the bribe.

The policing of sex work became entirely motivated by financial rewards, and the possibility of supplementing income, which most police 
officers view as wholly inadequate for supporting a family, ${ }^{91}$ became too much to resist. This was a radical shift from the previous strategy of ignoring sex work to focus on more serious crimes. Police attempted to partner with sex workers to extort their clients, but most sex workers refused such arrangements, as it would compromise their very livelihood and thus was not worth the associated risks.

${ }^{91}$ Police dissatisfaction regarding salaries, benefits, and opportunities for further education, while policing what they perceive as increasing disorder, is also relevant in understanding why corruption, brutality, and poor service delivery occur during the policing of sex workers and why these police appeared to genuinely miss apartheid. Police members argued that during apartheid, police members earned living wages and were treated with respect. However, this belief may be based more on a mythology of what it meant to be police during apartheid than on reality. DEBORAH JAMES, MONEY FROM NOTHING 15 (2014) (describing the experiences of middle class individuals, including several police officers, who must go into debt and are generally "unable to sustain their future dreams with their present income"). 
Figure 1. Relationships between sex work participants

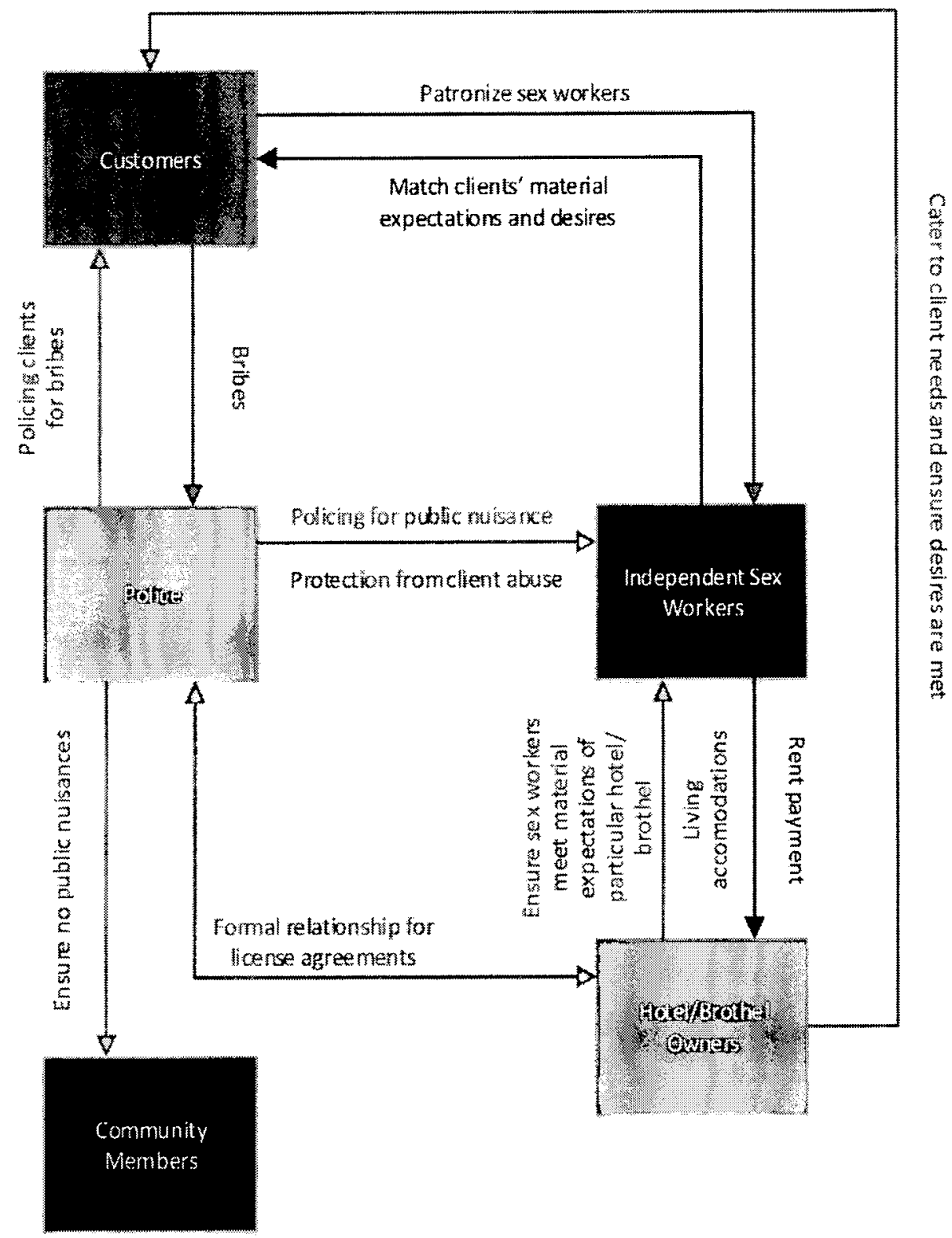

This diagram illustrates the interconnecting relationships between the various players in the Johannesburg sex work arena. Sex workers in Johannesburg are generally independent contractors. As the diagram in Figure 1 shows, there are interconnecting relationships in a sex work 
transaction. By affecting one component of the interaction, police were also affecting sex workers. Although the police did not return to arresting sex workers during this period of intense client scrutiny, their demands on the sex worker clientele began to severely upset the delicate market that existed in Rosebank. The male clients who purchased sex from Rosebank were ordinarily married, white, and middle to upper middle class. ${ }^{92}$ They frequented Rosebank because the sex workers who operated there were reputed to be "professional" and "beautiful" and because the location was conducive to relative invisibility. Oxford Road is near several of Johannesburg's wealthy northern suburbs and allows clients to be stealthy in their purchase of sex because of the location's proximity to their homes. The sex workers in Rosebank were also less visible than those operating from central Johannesburg. They were generally careful to be discreet, to remain hidden under shadows and in dark corners, and repeatedly bragged amongst themselves that they were "true professionals." $"$ Accordingly, Rosebank attracts a wealthy clientele, and the Rosebank police are highly sensitive to this fact. ${ }^{94}$ As a perverse manner of getting around human rights directives prohibiting the arrest of sex workers, police began targeting sex work clients, creating some devastating consequences.

As this criminalization of client activities intensified, police began demanding up to R7000, or approximately $\$ 700$ at the time, from clients,

92 Field Notes of India Thusi in Rosebank, S. Afr. (on file with author).

93 Rosebank is located in the upper-middle-class northern suburbs in Johannesburg. This section of Johannesburg's northern suburbs is home to many of the city's liberal elite, who are attracted by the road's tall trees and picturesque Johannesburg surroundings. The book Kaffir Boy describes Rosebank as "one of Johannesburg's posh whites-only suburbs," which reflects an apartheid-era description of the area. MARK MATHABane, KafFir BOY: THE TRUe StORY OF A Black Youth's COMING OF AGE IN APARTHEID SOUTH AFRICA 170 (1986). Now, Rosebank retains much of its historical "poshness" but is also considerably trendy and home to several media houses, and welcoming of Johannesburg's young, black elite. Sarah Nuttall, Stylizing the Self: The $Y$ Generation in Rosebank, Johannesburg, 16 PuB. Culture 430, 434 (2004) ("Rosebank is a suburb cum business district where sectors like information technology, retail, fashion, cinema, restaurants, and travel and tourism have been attracting a trendy and youthful workforce since the late 1980s.").

${ }_{94}$ Both Rosebank and Illovo are surrounded by suburbs that are family oriented, upper middle class, and home to Johannesburg's well-to-do. Oxford Road is surrounded by Hyde Park, Athol, and Houghton Estate, which are amongst the richest areas in the country with the highest concentration of multimillionaires. Joan Muller, SA's Most Expensive Streets, FINANCIAL MaIL, Nov. 13, 2013 ("Millionaires row in Johannesburg includes Culross Road and Eccleston Crescent in Bryanston, 4th Road in Hyde Park, Coronation Road in Sandhurst and Deodar Road in Atholl."); Study Reveals SA's Wealthiest Areas, IOL NEws (Aug. 29, 2012) (“Joburg areas dominate the list of wealthiest suburbs with the other top spots going to Bryanston with 31 multimillionaires, otherwise known as 'ultra high net worth individuals' or UHNWI, Hyde Park (26 UNHWIs), and Westcliff (20 UNHWIs)."). 
threatening that they would report them to their wives. The illegality of sex work had very little impact on the conversation; it was a negotiation whose currency was morality, driven by the clients' fear of exposure to their wives and families. Several sex workers complained about the incessant police corruption:

GRACIOUS: Right now they took R1000 [or $\$ 100$ ] from a client. When they [police] get money, they don't share. The client can come back and the client can be dangerous.

MELISSA: I had a client with a gun and he was extorted by the police. We went to do business and the police were waiting outside. They ask for bribes and say that you must pay to stand on this corner. You must pay, pay, pay. . . . If it's a white guy, they take so they don't want their wife to be told. If they [police] get 1000, they will give you 20. There were three Chinese guys who paid 1000 each [to the police]. They were driving a nice car. The police gave her 40 bucks. Luckily we did business, 200 each. It was a quick fuck, those guys cum fast.

CHRISTINA: The clients are scared of police and will pay 1000 in bribes. I feel like I'm working for the police. The police have stopped arresting the sex workers and have been engaging these extortion schemes instead. They are targeting the clients.

The police were mostly complying with their newly adopted "human rights approach" to policing sex work, which prohibited the arrest of sex workers. But they were subverting the law for their individual benefit; they were abusing their authority by making adopting a de facto partial criminalization model.

This shift towards extorting clients was the police's way of complying with policies to respect sex workers' human rights by eliminating the practice of frequently arresting them while continuing to police aspects of sex work. Rosebank police members indicated that they did not police sex workers themselves although they did police the conduct of clients. This approach is similar to the Swedish approach advanced by radical feminism in its focus on client criminalization and sex worker "protection." This case study illustrates the Swedish model in practice. The clients faced punishment from state actors, while the state actors left the sex workers alone. According to the radical feminist approach, this approach should eventually be the most beneficial to sex workers, and society in general by leading to the abolition of sex work. ${ }^{95}$

\section{B. The Arrest}

The dangers of the Swedish approach became clear to me on February 16,2016 , when sex workers called me about police arresting clients. I

${ }_{95}$ Ahmed, supra note 66 , at 229. 
headed to the address where sex workers directed me and noticed that there were sex workers outside and a parked Metro ${ }^{96}$ police vehicle. The private security officer and Metro police officer, Officer Lerato, allowed me to enter the parking bay after I explained that I was a researcher and that I had been working primarily with the South African Police Service. ${ }^{97}$ It was quite strange to see Metro police in Rosebank, because the Rosebank SAPS usually policed the sex workers in the area, whereas the Metro police were ordinarily based in central Johannesburg in the evenings. This was not an area that Metro should be policing. The Metro police officer informed me that he was concerned because he saw people he did not know in the parking bay. I asked him whether they were arrested, and he said, "no." I then asked him why they were being detained because I learned that they had been detained for three hours. One sex worker, Lucy, stated, "I came and the Metro entered in here. They asked what are you doing here." Officer Lerato informed me, "We still do not know what is going on here. We are still finding out what happened. We are still wanting to know what's happening. We are working to see what happened, maybe they have a bad reason to be here." Everyone was gathered in the parking lot, where sex work transactions often took place because the security officers had a special arrangement with the sex workers there. The Metro police were aware of this and decided to wait there to find clients whom they could extort.

After another hour of detention, one sex worker complained to me that she has a child and that "the baby does not even have milk. How will she eat? Last night I was dropped off by a client and the police asked for

${ }^{96}$ The Johannesburg Metropolitan Police Department was formed in 2001 by the Johannesburg Metropolitan Council to police local crime and engage in visible policing. Claire Bénit-Gbaffou, Unbundled Security Services and Urban Fragmentation in PostApartheid Johannesburg, 39 GeOFORUM 1933, 1941 (2008). The Metro police are focused on policing central Johannesburg. "One of the main aims of the service is to restore the public's confidence, and the key to this is visible policing", and this police department is charged with (1) policing road traffic, (2) enforcing municipal bylaws, and (3) enforcing municipal regulations. Metro Police - What is the function of the Metro Police Service? CITY OF JOHANNESBURG (Oct. 30 2006), http://www.joburg.org.za/ index.php?option=com_content\&id=38: metro-police\&Itemid=67\#ixzz3hDPSnTIL.

${ }^{97}$ With the rise of the National Party in 1948, the South African Police (SAP) became the main enforcement arm of the apartheid government, and the SAP has been described as the "medium through which apartheid was experienced." Benjamin Bowling et al., Policing and Human Rights: Eliminating Discrimination, Xenophobia, Intolerance and Abuse of Power from Police Work, 8, U.N. Res. Inst. for Soc. Dev. (2004) (presented in the United Nations Research Institute for Social Development Conference on Racism and Public Policy in 2011). Following the end of apartheid, the name of the police force was changed to the South African Police Service (SAPS) to demonstrate that the SAP would now serve the people. David Bruce, Unfinished Business: The Architecture of Police Accountability in South Africa, Afr. POLICING CInLIAN Oversight F., Nov. 2011, at 1. My participant observation work, including patrols and interviews, was with the Rosebank SAPS. 
500 rands. Today police asked for 500 rands for each of the sex workers present." The sex workers were concerned that these clients would not come back after the negative experience. One sex worker detailed the severity of the situation in Rosebank: "One of us is in hospital because of a client. You call the police and they don't help. They are committing a crime because of the money. After they collect their bribes they don't care about it hurts us." This sex worker was recounting an instance where a sex worker had called the police for assistance because her client was being abusive to her. The police come to the scene but instead of assisting with protection, they extorted a bribe from the client, and that client, in turn, became more physically violent with her and sent her to the hospital.

Backup Metro police officers arrived after another hour, and Officer Dharam came out of his vehicle wearing a bulletproof vest. He was in his mid-30s to mid-40s, and he quickly began to interrogate me. I complied with his questioning and provided him with my contact information. After speaking with him, I was ready to leave the site because the situation was getting tense and I was concerned that the police officers would become violent. As I pulled up to the gate to leave, Officer Lerato indicated that I could not leave. He appeared to be posturing, and despite my pleas to be released, I was stuck. In fact, the officers instructed a female officer to handcuff me, but I walked away from the exit and stated that I would not leave of my own accord. I walked down an alley, and the female officer followed me and stated she would use force on me if I did not come closer to the group.

I complied. The officers had now been talking for some time with the large group. The sex workers continued complaining about the lost income and time. I remained behind in a dark alley and slowly crept behind the building. When it seemed clear that no one was following me, I jumped over the fence, cutting my hands and ripping my pants. I then jumped over a second fence as sex workers watched from the outside and pleaded for me to be careful. Both of my hands were bleeding by this time. I ran into the Thrupps Shopping Centre and gestured for the sex workers to keep quiet. I quickly ran through the shopping center, dropped my bike helmet and jacket on the ground in the back of the parking lot, waved at the security guards, and made my way upstairs, skipping through the parking lot. I threw off my black jacket and donned a bright blue sweatshirt as I casually walked from Thrupps to my house so as to avoid looking suspicious. I arrived home, asked my husband for some assistance in retrieving my abandoned scooter, and waited for the Metro to leave the parking lot before speaking to the Securitas security staff about retrieving my bike.

Rosebank and Illovo sex workers called me endlessly the following day, each with different reports about Metro and SAPS officers asking clients for large bribes and clients, in turn, inflicting violence upon the sex 
workers. Many women vowed not to return to Rosebank, and for several weeks following this evening, the streets of Rosebank were nearly empty, with very few sex workers operating on a given evening. In early February 2014, I counted more than 100 sex workers outside one evening; in the evening of the day following my near-arrest, I could only find 2 sex workers on the streets, both of whom appeared to be new to Rosebank.

If nothing else, this experience indicates that upsetting the market for sex work can reap devastating consequences. In the Rosebank case study, de facto partial criminalization worked in its encouraging police officers to "respect" sex workers. However, the police found a fail-safe to get around these legal requirements by focusing on the clients and exploiting the conditions of sex work. Jean and John Comaroff describe "lawfare": "the resort to legal instruments, to the violence inherent in the law, to commit acts of political coercion, even erasure is equally marked in postcolonies. As a species of political displacement, it becomes most visible when those who 'serve' the state conjure with legalities to act against its citizens." ${ }^{98}$

The focus on client activities was a form of "lawfare,",99 an attempt to comply with human rights standards that have led police to remove their attention from the sex workers. The police members informed me that they did not police sex workers anymore because sex workers also have human rights. They were purposely adopting a policy that did not involve the frequent arrest and direct harassment of sex workers. They did not even cite the law when harassing clients. It was about morality and extorting the client's desires to remain invisible in the sex work transactions.

${ }^{98}$ Jean Comaroff \& John Comaroff, Law and Disorder in the Postcolony, 15 SoC. ANTHROPOLOGY 133, 144 (2007) (citations omitted).

${ }^{99}$ Id. 
Figure 2. Visual timeline of changes in the policing of sex work policing in Rosebank

\begin{tabular}{|c|c|}
\hline Date & Event \\
\hline July 2013 & $\begin{array}{l}\text { Informal decriminalization is in effect } \\
\text { Sex workers are recovering from prior arrests } \\
\text { Sex workers are recovering from prior news coverage by journalists }\end{array}$ \\
\hline August 2013 & $\begin{array}{l}\text { Informal decriminalization is in effect } \\
\text { Tension is low }\end{array}$ \\
\hline September 2013 & $\begin{array}{l}\text { Informal decriminalization is in effect } \\
\text { Police and sex workers are in agreement } \\
\text { No tension }\end{array}$ \\
\hline October 2013 & $\begin{array}{l}\text { Informal decriminalization is in effect } \\
\text { Police and sex workers are in agreement } \\
\text { No tension } \\
\text { Individualized nature of relationship is recognized }\end{array}$ \\
\hline November 2013 & $\begin{array}{l}\text { Informal decriminalization is in effect } \\
\text { Isolated incidents of police abuse, but generally informed by sex } \\
\text { workers that police have a policy of no arrests }\end{array}$ \\
\hline December 2013 & $\begin{array}{l}\text { Informal decriminalization is in effect } \\
\text { Increasing incidents of police targeting sex workers' customers }\end{array}$ \\
\hline $\begin{array}{l}\text { Late } \\
\text { December } 2013\end{array}$ & $\begin{array}{l}\text { Informal decriminalization is in effect } \\
\text { Reduced number of sex workers due to holidays and travel }\end{array}$ \\
\hline January 2014 & $\begin{array}{l}\text { Partial decriminalization is in effect } \\
\text { Heightened police surveillance of sex workers' customers } \\
\text { Extraordinary bribes }\end{array}$ \\
\hline February 2014 & $\begin{array}{l}\text { Partial decriminalization is in effect } \\
\text { Heightened police surveillance of sex workers' customers } \\
\text { Extraordinary bribes } \\
\text { I was arrested }\end{array}$ \\
\hline March 2014 & $\begin{array}{l}\text { Partial decriminalization is in effect } \\
\text { Heightened police surveillance of sex workers' customers } \\
\text { Extraordinary bribes } \\
\text { Drastic decrease of sex workers due to sex workers moving to other } \\
\text { locations }\end{array}$ \\
\hline April 2014 & $\begin{array}{l}\text { Partial decriminalization is in effect } \\
\text { Heightened police surveillance of sex workers' customers } \\
\text { Extraordinary bribes } \\
\text { Drastic decrease of sex workers due to sex workers moving to other } \\
\text { locations }\end{array}$ \\
\hline May 2014 & $\begin{array}{l}\text { Partial decriminalization is in effect } \\
\text { Heightened police surveillance of sex workers' customers } \\
\text { Extraordinary bribes } \\
\text { Drastic decrease of sex workers due to sex workers moving to other } \\
\text { locations }\end{array}$ \\
\hline
\end{tabular}




\begin{tabular}{|l|l|}
\hline June 2014 & $\begin{array}{l}\text { Partial decriminalization is in effect } \\
\text { Heightened police surveillance of sex workers' customers } \\
\text { Extraordinary bribes } \\
\text { Occasional number of sex workers }\end{array}$ \\
\hline July 2014 & $\begin{array}{l}\text { Partial decriminalization is in effect } \\
\text { Heightened police surveillance of sex workers' customers } \\
\text { Extraordinary bribes } \\
\text { Occasional number of sex workers }\end{array}$ \\
\hline August 2014 & $\begin{array}{l}\text { Partial decriminalization is in effect } \\
\text { Heightened police surveillance of sex workers' customers } \\
\text { Extraordinary bribes } \\
\text { Occasional number of sex workers }\end{array}$ \\
\hline February 2015 & $\begin{array}{l}\text { Partial decriminalization is in effect } \\
\text { Heightened police surveillance of sex workers' customers } \\
\text { Extraordinary bribes } \\
\text { Occasional number of sex workers }\end{array}$ \\
\hline
\end{tabular}

\section{A Consequentialist Analysis of Partial Criminalization}

Upon adopting a consequentialist approach to balance the harms of sex against the harms of criminalization and punishment, it is clear that the partial criminalization is not justified. The partial criminalization model looks inadequate in its focus on client criminalization because clients can always turn their gaze onto sex workers. This approach, in fact, may end up jeopardizing the safety of sex workers, who are often already in a precarious position. ${ }^{{ }^{100}}$ The sex workers themselves were experiencing more violence under partial criminalization as compared to the period of de facto decriminalization because the police were intensely focused on policing clients, and sex workers complained that clients were more hostile toward sex workers because of the scrutiny. Several sex workers began

100 As Noah Zatz has argued:

[C] riminalization has tended to isolate women from one another (as evidenced by laws making it illegal for a set number of women to live together), encourage dependency on pimps, and cut off mobility between prostitution and other forms of work: "Prostitutes were uprooted from their neighborhoods and had to find lodgings in other areas of the city and in the periphery. . . Cut off from other sustaining relationships, increasingly they were forced to rely on pimps for emotional security and for protection against legal authorities. Indeed, the wide prevalence of pimps in the early twentieth century meant that prostitution had shifted from a female- to a male-dominated trade, and there existed a greater number of third parties with an interest in prolonging women's stay on the streets." The form of prostitution encouraged by this historical process is one in which the subversive potential of prostitution is limited even while the supply of prostitutes is maintained.

Zatz, supra note 62, at 301 (internal citations omitted). 
working in locations that they previously avoided because of the harms they experienced at Rosebank. Under decriminalization, there was at least a provisional security in Rosebank. Under partial criminalization, the sex workers were exposed to more violence and felt less able to seek police assistance.

Moreover, the punishment of clients clearly harmed the sex workers by harming their source of income. Sex workers need clients to work. If one-half of the transaction is criminal, the sex workers cannot freely work. I received calls from several of the sex workers two weeks after the incident, asking for money to buy formula for their babies, or for food, and to otherwise meet their basic needs. ${ }^{101}$ The sex workers were concerned about their inability to work. Several of them indicated that they were the breadwinner for the family and needed sex work to provide for themselves and their children:

PRUDENCE: I wouldn't be standing here if there was another job. I am the breadwinner for my family. I have kids.

This case study highlights how partial criminalization may, in fact, create social harms to sex workers, which do not justify the punishment of clients under the radical feminist framework. It illustrates how examining the instrumentality of the punishment from the perspective of the sex worker allows you to consider unintentional harms of criminalization that might otherwise be overlooked. Criminalization resulted in a heightened violence against sex workers, and made those sex workers who relied upon their income to become even more desperate for money. Several of the sex workers worked in more dangerous locations and were unable to negotiate with clients because of the heightened scrutiny. ${ }^{102}$

\section{SEX WORK AS MANAGED RISK}

There are strong arguments for acknowledging the various contexts in which sex work occurs, particularly where marginalized women use it

101 Field Notes of India Thusi in Rosebank, S. Afr. (on file with author).

102 The harms of the Swedish model have been documented in other locations as well. Phil Hubbard et al., Regulating Sex Work in the EU: Prostitute Women and the New Spaces of Exclusion, 15 GENDER, PLACE \& CULTURE 137, 137 (2008) ("[T] he state and law may intervene in sex work markets with the intention of tackling gendered injustice, but are perpetuating geographies of exception and abandonment"); Arthur Gould, The Criminalisation of Buying Sex: The Politics of Prostitution in Sweden, $30 \mathrm{~J}$. Soc. POL'Y 437, 437 (2001) (acknowledging that Sweden's approach to sex work was driven in part by "fears about foreign prostitutes and ... Sweden's weak liberal tradition"); Susanne Dodillet \& Petra Östergren, The Swedish Sex Purchase Act: Claimed Success and Documented Effects 3 (2001), http://www.plri.org/sites/plri.org/files/ Impact\%20of\%20Swedish\%20law_0.pdf ("[S]erious adverse effects of the Sex Purchase Act-especially concerning the health and well-being of sex workers-in spite of the fact that the lawmakers stressed that the ban was not to have a detrimental effect on people in prostitution."). 
as a survival strategy. Kamala Kempadoo criticizes radical feminists for failing to recognize that "the global sex trade cannot be simply reduced to one monolithic explanation of violence to women" ${ }^{103}$ :

The agency of Brown and Black women in prostitution has been avoided or overlooked and the perspectives arising from these experiences marginalized in dominant theoretical discourse on the global sex trade and prostitution. Our insights, knowledges, and understandings of sex work have been largely obscured or dominated by white radical feminist, neo-Marxist, or Western socialist feminist inspired analyses that have been either incapable or unwilling to address the complexities of the lives of women of color. ${ }^{104}$

She argues that sex work should be treated as a form of labor. ${ }^{105}$ The role of race in the engagement of sex work should not be overlooked. She notes that " $[t]$ hrough recognizing sex worker agency it becomes possible to uncover resistances to, and contestations of, oppressive and exploitative structures and regimes as well as the visions and ideologies inscribed in women's practices." ${ }^{106}$

In a world of limited opportunities, sex workers manage risks and have made a calculated choice to adopt a profession within their existing economic paradigm. ${ }^{107}$ Sex work, for many, provides higher economic opportunities for women and men who otherwise face employment discrimination. ${ }^{108}$ In this manner, it is empowering and provides the sex worker with a lifestyle that would not otherwise be available. There have been efforts to empirically ground feminist legal theory and ensure its applicability in various contexts. ${ }^{109}$ However, the need to consider different contexts and how sex work may at times become a tool for female empowerment, particularly in the Global South and for women of color in the West, is critical. ${ }^{110}$ This perspective provides a lens for understanding the experiences of sex workers of color in different contexts.

103 Kamala Kempadoo, Women of Color and the Global Sex Trade: Transnational Feminist Perspectives, 1 MERIDIANS 28, 28 (2001).

104 Id. at 40.

105 See Kamala Kempadoo, Women of Color and the Global Sex Trade: Transnational Feminist Perspectives, 1 MERIDLANS 28 (2001).

${ }_{106}$ Kamala Kempadoo, Slavery or Work? Reconceptualizing Third World Prostitution, 7 Positions: E. Asia Cultures CrITIQue 225, 233 (1999).

107 Teela Sanders, A Continuum of Risk? The Management of Health, Physical and Emotional Risks by Female Sex Workers, 26 SOC. HeALTH \& ILLNESS 557, 558 (2004).

${ }_{108}$ See Alex Lindsey et al., What We Know and Don't: Eradicating Employment Discrimination 50 Years After the Civil Rights Act, 6 INDUS. ORgaNIZATIONAL PSYCHOL. 391 (2013) (discussing the persistence of employment discrimination on the basis of race, color, religion, sex, and national origin).

${ }^{109}$ See, e.g., Liz Stanley, Feminist Praxis and the Academic Mode of Production, in Feminist Praxis: Research, Theory and EPISTEMology in Feminist Sociology 3 (Liz Stanley ed., 2013).

${ }^{110}$ See Kempadoo, supra note 103, at 40. 
Radical feminism reflects white supremacy in its failure to adequately address the concerns of sex workers of color and consider that these women always face constrained choices and multiple systemic barriers. Sex workers who are also low-income, or who are also migrant, or who are also women, or who are also black, may already exist in a paradigm where they have limited choices because they exist in an order that prioritizes white supremacy, patriarchy, and wealth. "' Nonetheless, even under these conditions, and despite experiencing structural barriers, it seems repugnant to suggest that these women do not nonetheless have some agency. Adopting an intersectional lens makes it clear that one could almost always argue that women, particularly women with multiple identities, are making choices in a paradigm of structural disadvantage. ${ }^{112}$ Despite this, we cannot say that these women can never exercise any choice. ${ }^{13}$ To do so would silence these women and in turn makes the feminist advocates, who seek to liberate these women from their own false consciousness, the oppressors of these women, some of whom may choose sex work in light of their choices. ${ }^{114}$ It begets the question, who is really empowered in these discourses? ${ }^{115}$ The sex worker or the scholars or activists who feel they know better than the sex worker herself?

Furthermore, the radical feminist scholarship around female sexuality and sex work reproduces patriarchy. It is "[o]ften the argument is simply a circular appeal to "sex." "116 Discourses around sexuality often serve to reinforce the power of those dictating the sexual norms. While openly discussing sexuality and the role of sex workers serves to make the discussion more robust and transparent, it may also serve to reiterate models of sexuality that strengthen male dominance by presupposing that men sit at the top of the sexual hierarchy. Or are we to assume that men are naturally more sexual beings and thus the sole beneficiaries of anything relating to sex? We must question whether sex work is always sex. If we position ourselves in the place of the male client, then sex work is a sexual transaction. However, for some sex workers, sex work is solely work, not at all sex. It is not necessarily an expression of their sexual prowess, and they are not mere victims in the exchange of their services.

"I Crenshaw, supra note 83, at 1245.

12 Cf. Patricia Hill Collins, Learning from the Outsider Within: The Sociological Significance of Black Feminist Thought, 33 SOC. PROB. S14 (1986) (describing how black women sociologists occupy an "outsider within" status, demonstrating how limited choices and structural arrangements constrain choices even within the academy).

173 Id.

114 Id.

115 Audre Lorde, The Master's Tools Will Never Dismantle the Master's House, in FEMINIST POSTCOLONIAL TheORY: A READER 25 (Reina Lewis \& Sara Mills eds., 2003).

${ }^{116}$ Zatz, supra note 62, at 289. 
As Foucault has stated, to engage in discourse may be an expression of power in and of itself. ${ }^{17}$ Here, the radical feminist advocate or scholar appears to assert her power over and against the sex worker through a discourse of a singular woman who is a mere victim to sex. Such interpretation of sex work that relies upon the narrative of sex as solely a site for male dominance "produces the fiction of a universal sisterhood, bonded in its experience of victimization and violence. There is no space in this construction for difference or for the articulation of a subject that is empowered." 118 The radical feminist debate is overly reliant on this essentialization of sex.

To be clear, sex workers are exposed to increased risks. They are often victims, or rather survivors, ${ }^{119}$ and yet they have nonetheless developed mechanisms for managing these risks and have perhaps chosen to face the risks associated with sex work over those associated with abject poverty. ${ }^{120}$ Because sex work is not static, even within my three research sites, ${ }^{121}$ it is presumptively changeable and able to adapt to more ideal conditions. ${ }^{122}$ Sex workers live in a complicated reality and occupy contradictory spaces. ${ }^{123}$ They are not mere victims who require saving under any approach regarding criminalizing.

Ingrid $^{124}$ is a sex worker whose experiences highlight some of the complexities of sex work. A mutual friend introduced me to Ingrid. Alt-

117 Michel Foucault, The History of SeXuality 32 (Robert Hurley trans., 1978) ("[D] iscourses on sex did not multiply apart from or against power, but in the very space and as the means of its exercise.").

${ }^{118}$ Rarna Kapur, The Tragedy of Victimization Rhetoric: Resurrecting the "Native" Subject in International/Post-colonial Feminist Legal Politics, 15 HARv. HUM. RTS. J. 1, 36 (2002).

119 See Liz Kelly, et al., Beyond Victim or Survivor: Sexual Violence, Identity and Feminist Theory and Practice, SEXUALIZING THE SOC. 77 (1996) (discussing the dichotomy created in the use of victim or survivor to engage in meaning making in the feminist literature).

120 Lorraine Van Blerk, Poverty, Migration and Sex Work: Youth Transitions in Ethiopia, 40 AREA 245 (2008) (finding that "sex work provides a risky alternative, but often successful, path to independence" for migrants from rural to urban area in Ethiopia).

121 Within Johannesburg, this is a multi-site study, focused on how sex workers are policed in both indoor and street-based environments. This case study involves five research sites in three geographic locations. These research sites represent a fraction of the typology of the sex work that is in Johannesburg but are sufficiently unique to highlight the diversity of the industry.

122 See Part IV supra describing the changing conditions in Rosebank.

${ }^{123}$ Phil Hubbard \& Teela Sanders, Making Space for Sex Work: Female Street Prostitution and the Production of Urban Space, 27 INT'L. J. URB. REgIONAL REs. 75, 88 (2003) ("[I]t is always difficult for capitalist society to maintain the chaotic, contradictory spaces it has produced, and Lefebvre reminds us that new 'differential spaces' forged through bodily practice may explode through the repressive and calculating spaces of capitalism.")

${ }^{124}$ Name has been changed. 
hough she used to work at the Hillbrow Inn, I met her in Midrand, near where she now lives. When she first arrived in South Africa from Zimbabwe, she had to "squat" with her aunt for some time because she didn't have a place to stay. She eventually began working as a domestic worker. She was being paid very little and earned no more than R1500, or $\$ 150$, each month. As a domestic worker, she was working for a married man and his wife, the latter of whom was very suspicious of her husband. He told Ingrid that she was a "pretty girl" and promised to take care of her. She soon left this employment.

One day, she saw a group of male friends with some "beautiful ladies who worked at Royal Park." The ladies bought all the guys drinks and told Ingrid, "You can use your body to do that yourself." Ingrid asked the guys she was with where to go, and she soon started working at the Hillbrow Inn. The money she was earning was "too much." Ingrid bought a fridge for $\mathrm{R} 4000$, or $\$ 400$, earned in one week. She would go to restaurants, such as Ocean Basket, the South African equivalent to Red Lobster, and enjoy life in ways she could not have before beginning sex work. She did not want to do this work, but it provides her with a lifestyle that was otherwise beyond reach for her. Ingrid has two brothers, a mother, and two kids. She is the breadwinner in the family, and she "sacrificed for the family."

As Ingrid frequently told me, "it's not about men or sex, just money. . . It wasn't easy [to do this]. This work can sometimes be humiliating." One client failed to pay her for services rendered. She was very upset because she went to his place for the transaction and he failed to compensate her. She recounted, "I need my money, and you wasted my time. I can't waste money." She had been with this client for two days. His wife learned of his infidelity and returned home early from a family trip to her mother's house. When the wife arrived, Ingrid informed the wife that she was just a friend and that she did not want her husband. Ingrid, who is in her early $30 \mathrm{~s}$, said that she was just passing through and that both the wife and the husband were younger than her. "Why would your husband want me? I'm old."

However, the husband had not yet paid her for the services she had rendered, and she waited there from 10:00 a.m. to 4:00 p.m. as the husband and wife argued. She finally left, but not before she had an opportunity to take his identification and phone number as insurance of future payment. Once the husband realized he was missing his personal items, Ingrid was eventually compensated. Ingrid found a strategy for adapting to the uncertainty of future payment for services that had already been rendered. Ingrid recently quit working at Hillbrow Inn and has become a domestic worker earning R4000 per month.

During the course of my ethnography, dozens of sex workers I interviewed echoed Ingrid's story. Most of them did not want to do sex work, but they enjoyed the financial freedom it provided. Sex work allowed 
them to provide for their families but also exposed them to certain occupational hazards. Yet these hazards were negotiated by a system of coping mechanisms that allowed sex workers to minimize the risks. Sex workers often recounted working several sex work hot spots before settling on a location where they felt comfortable. They often worked with friends and were able to check out potential clients before entering their cars. Several sex workers had police clients whom they would call if they were having issues with other clients. They found ways to manage the risks of their occupation.

By contrast, radical feminism focuses on a conception of women sex workers as one-dimensional victims, but victims are not empowered. ${ }^{125}$ They require help and by definition are subject to the authority of those who deem them helpless. ${ }^{126}$ Although scholars who engage in sex-workeras-victim debates presumably aim to help or save the sex worker victim, they are simultaneously depriving sex workers of aspects of their selfdetermination, while ignoring their voices in the debates about what is best for them. "Most simply, sex workers' own understandings of their lives, and the ways of living embedded in those forms of understanding, are themselves part of the phenomenon under investigation." ${ }^{\text {"27 Radical }}$ feminism disempowers sex workers by advocating for a world where they do not have the choice to manage the risks.

The sex worker was not merely a victim; she made choices but nonetheless had to manage real risks and dangers associated with her job. Treating sex workers as victims is an understandably attractive option. After all, it's easier to support policies for victims. However, we must question whether, in the denunciation of sex work and the relegation of its workers to victimhood, radical feminism reinforces male sexual hegemony predicated on the assumption that women are helpless and require protection as they are unable to remain emotionally detached during sex. ${ }^{128}$ Men are not perceived as victims in sex work transactions because they are presumed to be emotionally detached from the sex, viewing it merely as physical release. ${ }^{129}$ Can't the women be similarly detached, viewing sex as a mere physical act for obtaining money? Furthermore, in adopting a radical feminist approach, do we not simply strengthen arguments that underlie patriarchy and systems that deny female expressions of open sexuality and ability to exploit their sexuality? Several domestic

125 Victim, OXFORD DICTIONARY OF ENGLISH (3d ed. 2010).

126 See Doezema, supra note 77, at 16.

197 Zatz, supra note 62, at 285.

128 Aya Gruber, Neo-Feminist Assessment of Rape and Domestic Violence Law Reform, 15 J. GENDER RACE \& JUST. 583, 601 (2012).

${ }^{129}$ See Overall, supra note 5, at 720; see also Jeffery P. Dennis, Women Are Victims, Men Make Choices: The Invisibility of Men and Boys in the Global Sex Trade, 25 GENDER Issues 11, 16 (2008) (surveying the lack of study of male sex workers in the social science literature). 
workers in South Africa have confided in me that they feel degraded by their work or would choose other work under more ideal circumstances. ${ }^{130}$ Should their form of labor also be criminalized to protect their dignity? Is sex for work really so different from other types of body labor in exchange for income?

Abolitionist arguments are problematic because they rely upon the essentialization of sexuality, womankind, and sex. They reify patriarchy by assuming that sex is necessarily harmful to women without acknowledging circumstances where women are able to exploit the desires of men to their economic benefit. They are premised on the notion that sex is necessarily an oppressive act for women and that women are incapable of separating their bodywork from their personal selves. These arguments also completely ignore the autonomy of the individual sex worker subjugating her choices for the better of a larger structure, which works against her individual interests. Abolitionists frequently argue for the Swedish model for sex work regulation as a universally suitable approach. ${ }^{131}$ However, making women who are desperate for work even more desperate for their primary source of income seems harmful.

Moreover, to destructively declare sex work advocates as victims of false consciousness while silencing the voices of sex workers with opposing views is a form of violence against the sex worker victim whom the radical feminist presumably aims to protect and save, and itself seems to be a harm from this model. ${ }^{132}$ The monolithic narrative of the sex worker as victim, without appreciation of the nuances of various sex worker life situations, variations between different classes of sex workers, or disregard for the colonial or post-colonial contexts of particular sex workers, serves only to benefit discussants promulgating a particular moral agenda, colored by their perceptions of appropriate female conduct.

\section{A. Freedom from Punishment Means Freedom to Resist}

It is important to appreciate that even the most exploitative of power relations present complexities. As Foucault has argued, discourses around sexuality and power relations defining them are not onedimensional. ${ }^{133}$ "Foucault's post-structuralist theory posits the emergence

${ }^{130}$ Bonnie Thornton Dill, "Making Your Job Good Yourself": Domestic Service and the Construction of Personal Dignity, WOMEN \& POL. OF EMPOWERMENT 33, 36 (Ann Bookman \& Sandra Morgen eds., 1988) (discussing the strategies that domestic workers adopt to construct dignity under demeaning conditions); Jennifer Bickham Mendez, of Mops and Maids: Contradictions and Continuities in Bureaucratized Domestic. Work, 45 Soc. PROBS. 114, 117 (1998).

${ }^{131}$ Dodillet \& Östergren, supra note 102, at 2.

${ }_{132}$ Michael Adorjan et al., Stockholm Syndrome as Vernacular Resource, 53 Soc. Q. 454,455 (2012) (describing the instrumental use of Stockholm syndrome in prostitution debates).

${ }^{138}$ FOUCAULT, supra note 117 , at 32-34. 
of peculiarly modern forms of power that operate via mechanisms of normalization rather than authority and command." ${ }^{134}$ Within these discussions around sexuality, there may be expressions of resistance. South African sex workers have historically been penalized and tolerated, regarded as charlatans and renegades, as sites of contagion and disease, yet treated as necessary evils. ${ }^{135}$ Within the complexity of the competing views towards the existence of sex work, sex workers have been both required and disdained; they have managed to push the discourse around sexuality and have served as a resisting force against conservative morality around sexuality. ${ }^{136}$ Nonetheless, the very act of sex work may be perceived as an exertion of sex workers' power through the resistance of the male patriarchal system that relegates female sexuality to private expressions of domesticity. ${ }^{137}$ And the economic aspect of sex work simply cannot be ignored. Money is how men have long controlled womenmarriage, which has been a site for the exercise of patriarchy and male dominance, ${ }^{138}$ has historically been about money and access to power. ${ }^{139}$ Sex workers have frequently benefited from the economic independence that sex work has afforded them. ${ }^{140}$ Accordingly, criminalization results in greater net social harm by prohibiting sex workers from enjoying this benefit.

Sex work advocates have argued that sex workers' sexual autonomy is not compromised because they retain the right to withdraw the contract

${ }^{134}$ Vanessa E. Munro, Legal Feminism and Foucault-A Critique of the Expulsion of Law, 28 J. L. \& Soc'y 546 (2001).

135 I. India Thusi, Policing Sex: The Colonial, Apartheid, and New Democracy Policing of Sex Work in South Africa, 38 FORDHAM INT'L L.J. 205, 206-07 (2015).

${ }^{136} I d$. at 218.

137 Kempadoo, supra note 103 , at 39.

${ }_{138}$ See, e.g., Grace H. Chung et al., Wives' Relative Income Production and Household Male Dominance: Examining Violence Among Asian American Enduring Couples, 57 FAM. REL. 227, 228-29, 234-35 (2008).

139 Anita Bernstein, For and Against Marriage: A Revision, 102 MrCH. L. REv. 129, 133 (2003).

140 Anne McClintock, Screwing the System: Sexwork, Race, and the Law, 2 BOUNDARY 70,72 (1992). McClintock discusses the paradox in the relationship between sex work client and sex worker:

The moment of paying a female prostitute is structured around a paradox. The client touches the prostitute's hand in a fleeting moment of physical intimacy in the exchange of cash, a ritual exchange that confirms and guarantees each time the man's apparent economic mastery over the woman's sexuality, work, and time. At the same time, however, the moment of paying confirms precisely the opposite: the man's dependence on the woman's sexual power and skill. Prostitutes stand at the flash points of marriage and market, taking sex into the streets and money into the bedroom. Flagrantly and publicly demanding money for sexual services that men expect for free, prostitutes insist on exhibiting their sexwork as having economic value. 
at will. ${ }^{111}$ Peter de Marneffe argues that sex work contracts should be treated in the same way as other labor contracts involving hazardous conditions. ${ }^{142}$ Although the law has prohibited contracts that are voided due to public interest rationales, there may be reasons for it to be particularly careful about labor contracts, especially in contexts where limited labor options provide similar economic benefits in developing countries. ${ }^{143}$ Sex workers frequently express their experiences as a form of dual consciousness of resistance and choice. ${ }^{144}$ Sex work does not fall neatly into a binary of choice or victimhood. There is frequently a contingent choice, which can be explored in Foucauldian terms.

[The] Foucaultian conception of power as a force which bears out its effects on every social agent, rather than as a commodity to be wielded in the interests of the socially privileged to maintain the ongoing derision of the socially subordinate has been welcomed by contemporary feminist theorists who have become increasingly dissatisfied with the more totalitarian arguments of the radical genre. $^{146}$

Accordingly, there is no centralized form of power, and power can be expressed through resistance. Power is diffuse and cannot be attributed singularly to one source. ${ }^{147}$ In this way, sex workers are subject to male subordination and patriarchy. Like all women, they still manage to retain some power and may express resistance to their subordination. They are still able to organize and exert power against the subordination through their resistance. The denial of this ability is critical to radical feminist arguments. However, the only thing that separates those feminists from their sex worker "sisters" is that sex workers exert their power through sex rather than scholarship. Is the choice to be a scholar under male patriarchy really much different than the choice to be a sex worker? Why can we exercise our choice and not them? The only reasonable answer is that there is something about sex itself that creates a bar to this. But who should decide whether sex should make the difference? From the perspective of the sex worker, the community that criminalization is intended to protect under radical feminist approach, criminalization limits her ability to exercise resistance and counteract patriarchy.

${ }^{141}$ Laurie Shrage, Should Feminists Oppose Prostitution, 99 ETHICS 347 (1989).

${ }_{142}$ See Peter De Marneffe, Avoiding Paternalism, 34 PHIL. \& Pub. AFF. 68, 93-94 (2006).

${ }^{143}$ Id. at 94.

${ }^{144}$ Lisa E. Sanchez, Sex, Law, and the Paradox of Agency and Resistance in the Everyday Practices of Women in the "Evergreen" Sex Trade, in ConstrTutive Criminology at WORK: APPLICATIONS TO CRIME AND Justice 43-44 (Stuart Henry \& Dragan Milovanovic eds., 1999).

${ }^{145}$ Id. at $43-44,54$.

146 Munro, supra note 134, at 549.

${ }^{147}$ FouCAULT, supra note 117 , at $32-34$. 
Hegel speaks of development as occurring in three stages. ${ }^{118}$ The savage person is at the first stage of development in and of itself. ${ }^{149}$ She is the freest, capable of acting with no regard for rules or the confines of society. Once the person has been forced into a state society, she becomes enslaved. ${ }^{150}$ She must comply with the social norms of that state, be restricted by its rules, and comply with the norms it dictates. In this stage, she is no longer liberated and is confined. The third stage of development, the person as a citizen of a state, leads to ultimate freedom. She is now able to achieve tasks and experience a brand of liberty not available to her in her savage state. ${ }^{151}$ This is the ultimate freedom, which is realized once a person enters into a civilized society. ${ }^{152}$ In her bondage, she has been set free. ${ }^{153}$ In the various stages of development, she is in the process of becoming and evolving into something even freer than what she originally was.

Perhaps the same can be said about the woman who has chosen to engage in sex work. The initial entry into sex work may be a form of bondage if it is ultimately a profession that she would not choose for herself but rather tolerates because of her economic circumstances. She is bound by its unusual circumstances, demanding clients, and the whims of police members who regulate her activities in environments where they are deemed criminal. Before entering the sex work profession, she is quite literally free-er. However, in her process of becoming and through the act of sex work, she evolves into someone who is actually freer because of her engagement with sex work. In this sense, sex work becomes an agent for empowering sex workers and provides them with opportunities. In this sense, sex work might become an agent for empowering sex workers and provides them with opportunities. She is now possibly able to afford better care for her child, provide a better lifestyle for her family, and enjoy a life that would otherwise be unavailable to her.

Sex work, when viewed as such, can change lives and create greater freedom from the male patriarchal structures in its ability to change the economic reality of sex workers. The question then becomes whether economics is an accurate measure for assessing freedom. In capitalist societies, it is undoubtedly a measurement, if not the measurement. ${ }^{154}$ Money affords its holders access to opportunities otherwise unavailable. Suggesting that sex work can empower sex workers provides many moral dilemmas. For many, on its face, it is a suggestion that is morally repre-

148 G.W.F. Hegel, PhenOMENOLOGY OF SPIRIT (A.V. Miller trans., 1977).

149 Id.

${ }^{150} I d$.

151 Id.

${ }_{152} I d$.

153 Id.

154 GEORge Gilder, WeAlth AND POVERTY: A NeW Edition fOR the TWENTY-First CENTURY 92, 102 (2012). 
hensible and should be avoided at all costs. As Embrace Dignity argues in South Africa, if women must resort to sex work, then we must do more to create economic empowerment and economic freedom. ${ }^{155}$ This argument is fine and should be considered; however, it does not preclude sex work as an alternative avenue for seeking such freedom. Various approaches can be adopted to encourage the same outcome. There is nothing to prohibit this from occurring. Rather, sex work should not automatically be excluded as a possible approach, especially for women with limited economic options.

Feminist discourses should focus on how to improve and create the ideal conditions for sex workers in practical terms. Prabha Kotiswaran has suggested that there is a middle ground for feminism that allows for the consideration of sex workers as agents without going as far as the "sex work advocate" approach. ${ }^{156}$ She claims that the majority of feminists are actually situated somewhere in the middle and that there is room for the tolerance of sex work as a form of labor. ${ }^{157}$ She suggests that material feminism provides a mode for understanding the evolution of sex work in its sensitivity to the historical position of gender and other structures to understand gender. ${ }^{158}$ Material feminism recognizes that gender implications are situated within a particular historical context and reflect the political economy of the time. ${ }^{159}$ This approach is favorable in its recognition of female social positions as shifting.

Within the particular context of Johannesburg sex workers, all the women with whom I interacted were independent workers. Almost all of them had children, and none of them were skilled to engage in work outside domestic work in South Africa. In a country with 30 percent employment, ${ }^{160}$ it is difficult to fathom outlawing, or abolishing, the primary means of work that allows these women to provide a better financial lifestyle for their families than otherwise available. They were managing their risks within a particular societal context. "In prostitution, the consequences of risk are different across markets because different catego-

${ }^{155}$ Letter from Nozizwe Madlala-Routledge, Exec. Dir., Embrace Dignity, to Baleka Mbete, Speaker, Nat'l Assembly and Thandi Modise, Chairperson, Nat'l Council of Provinces, (Dec. 10, 2014) (on file with Parliamentary Monitoring Group), http://pmg-assets.s3-website-eu-west-1.amazonaws.com/160302Embrace_Dignity.pdf :

[O] ur concern is the lack of understanding of the harms of the prostitution and its links to sex trafficking. Without addressing prostitution and all forms of commercial sexual exploitation, our effort to end gender oppression and sexual violence will continue to be undermined.

${ }^{156}$ Prabha Kotiswaran, Born unto Brothels-Toward a Legal Ethnography of Sex Work in an Indian Red-Light Area, 33 L. \& SOC. INQUIRY 579 (2008).

157 Id.

$158 I d$.

$159 I d$.

${ }^{100}$ Stephan Klasen \& Ingrid Woolard, Surviving Unemployment Without State Support: Unemployment and Household Formation in South Africa, 18 J. AFR. ECON. 1 (2009). 
ries of women have different risk profiles.... They have different degrees of control over their exposure to these risks." ${ }^{161}$ Sex workers in Johannesburg adopt various strategies to protect themselves against the inherent dangers of their profession, but none of them had been coerced into the business. Abolitionist models ignore the economic realities of developing countries, the post-colonial social condition, and the racist institutions that make economic freedom challenging for many women of color in the West.

Police members in Hillbrow acknowledged the economic necessity of sex work for many women and suggested that decriminalization might actually reduce crime against sex workers:

DENI: Prostitution is done because of poverty. Poverty is the reason why there is prostitution .... Legislation and legalizing might drop rapes.

Most of the police officer I interviewed supported decriminalization. Police participants were asked whether prostitution should be decriminalized.

Table 1. Police interviewees' opinions on decriminalization of sex work

\begin{tabular}{llll}
\hline Should prostitution be decriminalised? & Yes, $\mathrm{n}(\%)$ & No, $\mathrm{n}(\%)$ & Total, $\mathrm{n}(\%)$ \\
\hline Hillbrow & $15(78.9)$ & $4(21.1)$ & $19(100)$ \\
Rosebank & $5(100)$ & $0(0)$ & $5(100)$ \\
\hline
\end{tabular}

Table 1 presents a frequency table for the responses of Hillbrow and Rosebank police interviewees. As observed, a majority of the participants, with 15 (78.9 percent) from Hillbrow and all $(n=5)$ from Rosebank, responded that prostitution should be decriminalized. Only a minority from Hillbrow ( $\mathrm{n}=4,21.1$ percent) responded that prostitution should not be decriminalized.

As Sanders has observed,

[W]omen use space strategically to avoid physical violence, arrest, criminalization and harassment. The debates of agency and victimhood within prostitution have set out the complex parameters of whether a woman can consent to sell access to her body parts or whether all forms of prostitution are exploitative. ... In this sense, the space on which women rely to advertise, negotiate and supply commercial sex is strategically used to their advantage in order to make cash and minimize chances of harm. ${ }^{162}$

An appreciation of the power relations leads to an acknowledgement that sex workers' voices should be included when discussing policies and the-

161 Teela Sanders, The Risks of Street Prostitution: Punters, Police and Protesters, 41 URBAN STUdIES 1703, 1704 (2004), http://journals.sagepub.com/doi/pdf/10.1080/ 0042098042000243110.

${ }^{162}$ Id. at 1708. 
ories that implicate them. While the radical feminist scholarship is rife with examples of women are enslaved by the trade, ${ }^{163}$ the organized efforts of sex workers are overwhelmingly supportive of policies that facilitate the decriminalization of sex work. ${ }^{164}$ Moreover, in discussing the harms of sex work, the voices of sex workers themselves have been subordinated to the creation of a population that would continue to maintain the social hierarchy of the privileged feminist. Harms are considered as if the very definition of harm is not subject to cultural reinterpretations and reflective of white supremacy. A consequentialist model that prioritizes the perspective of sex workers acts is thus crucial.

Below is a chart analyzing the competing harms of sex work as compared to those of criminalization. It is consequentialist in focus on stated consequences of sex work and intersectional in its consideration of how these harms affect different communities.

Table 2. Summary of Application of Consequentialist Model

\begin{tabular}{|c|c|c|}
\hline $\begin{array}{l}\text { Harms } \\
\text { of Sex Work }\end{array}$ & $\begin{array}{l}\text { Harms } \\
\text { of } \\
\text { Criminalization }\end{array}$ & Harm Analysis \\
\hline $\begin{array}{l}\text { Sex work } \\
\text { commodifies sex }\end{array}$ & $\begin{array}{l}\text { Criminalization } \\
\text { results in a loss of } \\
\text { comparable } \\
\text { income }\end{array}$ & $\begin{array}{l}\text { The commodification of sex matters only to the } \\
\text { extent that sex can be essentialized and carry the } \\
\text { same meaning across cultures and experiences. } \\
\text { However, the essentialization of sex reaffirms } \\
\text { traditional gender roles and limits sex as a site of } \\
\text { resistance. Radical feminists rely upon a singular } \\
\text { understanding of female sexuality that } \\
\text { reinforces the notion that women are docile and } \\
\text { passive recipients of sex, who can only be } \\
\text { reduced to their victim status. } \\
\text { Higher income and elevation of lifestyle } \\
\text { presents real concerns that we all encounter, } \\
\text { especially for individuals who sit at the margins. }\end{array}$ \\
\hline $\begin{array}{l}\text { Affects male } \\
\text { perceptions } \\
\text { of women }\end{array}$ & $\begin{array}{l}\text { Stigmatizes sex } \\
\text { workers }\end{array}$ & $\begin{array}{l}\text { The radical feminist harm may be legitimate. } \\
\text { However, the question is whether } \\
\text { criminalization is the appropriate mode to } \\
\text { address this harm. Women who work as teachers } \\
\text { and nurses may reaffirm men's perceptions of } \\
\text { women as caretakers. Yet, these professions } \\
\text { should not be criminalized because they support } \\
\text { stereotypes that some women would consider to } \\
\text { be harmful. }\end{array}$ \\
\hline $\begin{array}{l}\text { No liberty to } \\
\text { make choice } \\
\text { because of } \\
\text { patriarchy }\end{array}$ & $\begin{array}{l}\text { Eliminates ability } \\
\text { to make any } \\
\text { choices given } \\
\text { patriarchy affects } \\
\text { all aspects of life. }\end{array}$ & $\begin{array}{l}\text { An intersectional analysis is particularly useful in } \\
\text { highlighting that some women always endure } \\
\text { multiple systems of oppression. Yet, these } \\
\text { women should be allowed to exercise choices } \\
\text { that allow them to navigate these systems. }\end{array}$ \\
\hline Violence & $\begin{array}{l}\text { Violence against } \\
\text { sex workers }\end{array}$ & $\begin{array}{l}\text { Violence may be a feature of sex work regardless } \\
\text { of whether it is criminalized. However, violence }\end{array}$ \\
\hline
\end{tabular}

16s See, e.g., MacKinnon, supra note 6, at 448.

${ }^{164}$ See Kotiswaran, supra note 46 , at 579 (highlighting that sex work advocates generally take a stance in favor of decriminalization). 


\begin{tabular}{|l|l|l|}
\hline & $\begin{array}{l}\text { may be reduced through decriminalization as } \\
\text { sex workers in Rosebank were more willing to } \\
\text { seek police assistance. }\end{array}$ \\
\hline $\begin{array}{l}\text { Should not have } \\
\text { to make this } \\
\text { choice based on } \\
\text { economic }\end{array}$ & $\begin{array}{l}\text { Serves an } \\
\text { expressive } \\
\text { function, which } \\
\text { stigmatizes sex } \\
\text { work }\end{array}$ & $\begin{array}{l}\text { Perhaps. But, how is it different from other } \\
\text { difficult choices that communities at the margin } \\
\text { face? }\end{array}$ \\
\hline
\end{tabular}

\section{RECOMMENDATIONS}

Although sex work is often dangerous and may include harms, decriminalization can often mitigate these harms. ${ }^{165}$ Accordingly, decriminalization seems suitable in most contexts in its recognition of the sex worker's autonomy and liberty. ${ }^{166}$ However, a singular model for sex work regulation should not be transposed to all contexts. The treatment of sex work must be localized. As seen during the course of my ethnography, there is no singular sex work, even within the same city or the same locality. Sex work is continuously shifting, and its formations are vulnerable to minor geopolitical changes. The appropriate regulation of sex work will vary by location and may require different solutions to accommodate this. Stark economic realities make sex work a viable option for some women. Taking away these women's clients does nothing to redress their economic situation and treats them as infants incapable of independent decision-making. In this way, a perspective that is decidedly intersectional, that is sensitive to overlapping systems of oppression by considering the sex workers' gender, race, and economic status allows for a nuanced analysis of the realities of using sex for work. Several sex workers, all of whom were black women with no comparable economic alternatives, articulated the economic realities that brought them to their work:

ANNIE (Rosebank sex worker): I come every day for money. I have children. The hotels are full so I'm working in the street.

CATHI: They are taking our clients. The clients now know about it that in Rosebank that the police take money. This is our money. These Rosebank police must stop, Norwood (police) must stop. Some are from Norwood and Johannesburg Central. Our clients are under threat. We are raising our children and we need this money.

${ }^{165}$ See Policy and research on protection of sex workers'rights, AMNESTY INT'L (May 26, 2016), https://www.amnesty.org/en/latest/news/2016/05/amnesty-international-publishespolicy-and-research-on-protection-of-sex-workers-rights/; See also AMNESTY INT'L, SEX Workers at Risk: A Research Summary on Human Rights Abuses Against SeX WORKERS (2016)

${ }^{100}$ Chi Mgbako \& Laura A. Smith, Sex Work and Human Rights in Africa, 33 Ford. INT'L L.J. 1178, 1208 (2010). 
A managed risks approach, which is consistent with consequentialism, requires a more nuanced understanding of harm. ${ }^{167}$ In determining whether conduct is harmful, there should be an evaluation of the competing harms that criminalization may cause and whether these harms can be reasonably managed. ${ }^{168}$ To ensure that criminalization does not contribute to the marginalization of legal outsiders, risks should be evaluated from the perspective of those who will be directly impacted by the conduct that is criminalized. ${ }^{169}$ There are circumstances where it makes sense to allow individuals to manage competing risks. ${ }^{170}$ In fact, it may cause greater harm to prevent individuals from engaging in sex work

${ }^{167}$ Cf. Michael L. Rekart, Sex-Work Harm Reduction, 366 LANCET 2123 (2005) (outlining successful harm reduction programs that manage the risks that are associated with sex work).

${ }^{168}$ Dawn Whittaker \& Graham Hart, acknowledged that the hetereogenity of sex work means that the sex work may be associated with lesser or greater harms depending on its social conditions:

$[T]$ he women in this study were accorded a greater degree of protection than might otherwise be expected, mainly because of the social organisation of sex work using rented flats as a base, and working collaboratively with maids to control and manage clients, as far as this is possible. In certain circumstances the women can also be very proactive, and have greater control over and influence upon the working environment-this particularly applies as they gain more experience of sex work, and seek out more 'sympathetic' and responsive landlords. This in turn may extend to and facilitate greater control over client interactions. It is necessary to undertake a variety of studies of the different sectors of prostitution as there is a clear association between the social organisation of sex work and exposure to harm in the working environment.

Dawn Whittaker \& Graham Hart, Research Note: Managing Risks: The Social Organisation of Indoor Sex Work, 18 SOc. HeAlth \& ILLNESS 399, 412 (1996).

169) See Sanders, supra note 107, at 559 (noting that sex workers "actively weigh up the costs and benefits of an action and make calculated decisions to determine the outcome. The probability of encountering risks is not only determined by varying dispositions to risk taking and risk avoidance but also by competing preferences.").

${ }^{170}$ A managed risk approach goes hand in hand with an approach focused on harm reduction. In the Netherlands,

The Dutch being sober and pragmatic people, they opt rather for a realistic and practical approach to the drug problem than for a moralistic or over-dramatized one. The drug abuse problem should not be primarily seen as a problem of police and justice. It is essentially a matter of health and social well-being. Changes in the traditional drug policy began to occur in the Netherlands as early as 1972. In that year the Narcotics Working Party published a document concluding that the basic premises of drug policy should be congruent with the extent of the risks involved in drug use (Narcotics Working Party 1972). This policy change led to the adoption of a revised Dutch Opium Act in 1976, when a distinction was made in the law between drugs of "unacceptable risk" (heroin, cocaine, amphetamines, and LSD) and drugs with lower risk such as marijuana and hashish. Commenting on this distinction, Engelsman notes: "In this regard the Dutch prove very pragmatic and try to avoid a situation in which consumers of cannabis suffer more damage from the criminal proceedings than from the use of the drug itself."

Marlatt, supra note 13, at 784 (internal citations omitted). 
even after factoring in all the harms that currently exist when engaged in selling sex. This analysis should be specific to local conditions.

In South Africa, there is a 23 percent unemployment rate, and for many women, sex work is the only way to afford a middle-class lifestyle. ${ }^{171}$ In many localities in the United States, the realities of an unjust criminal justice system may be reason enough to forgo any attempts to criminalize any aspect of sex work. ${ }^{172}$ By relying upon criminal law as the mode for eradicating the harms of sex work, feminists have strengthened an institution that was designed to control and manage marginalized communities. ${ }^{173}$ The focus on the structural harms of sex work in the abstract has often failed to factor in the structural harms of criminal law and the legal system. Individuals who deal with overlapping systems of oppression, for example, black women who face patriarchy and racial subordination, often must negotiate several risks or harms. ${ }^{174}$ To strip these individuals of tactics that they have adapted for maintaining a decent existence may be counterproductive in some instances, and oppressive in others.

Most of the police officers and sex workers I encountered during my research favored decriminalization. Although I agree with the sex workers and police members I encountered that sex work should be decriminalized in Johannesburg, I do not think that the question of how sex work should be treated stops there. There are strong reasons why sex work should not be criminalized, ${ }^{175}$ but there should be an infrastructure in place that guides police on how to interact with sex workers. Furthermore, over-emphasizing formal criminalization, even if only of clients, places too much confidence on the penal system to address issues relating to sex work. ${ }^{176}$ The history of the policing of sex work in South Africa reveals that sex work has mostly been policed informally and treated as a public nuisance matter. ${ }^{177}$ In any given locale, policies should reflect the

171 Klasen, supra note 160 , at 1.

172 See Part IV supra about a presumption against punishment.

173 See Gruber, supra note 128 , at 584.

174 See Crenshaw, supra note 83 , at 1245.

175 For an overview of the various debates concerning the decriminalization of sex work, compare Kathryn Abrams, Sex Wars Redux: Agency and Coercion in Feminist Legal Theory, 95 Colum. L. REV. 304, 328-29 (1995); Carole S. Vance, More Danger, More Pleasure: A Decade After the Barnard Sexuality Conference, in PleASURE AND DANGER: EXPLORING FEMALE SEXUALITY, at xvi-xvii (1992) (critiquing radical feminist approaches to sex work that view women as victims), with KATHLEEN BARRY, FEMALE SEXUAL Slavery 9 (1979), and ANDrea DWorkin \& CATHARINe A. Mackinnon, Pornography AND CIVL RIGHTS: A NEW DAY FOR WOMEN'S EQUALITY 25 (1988) (treating sex work as inherently problematic and violent for women).

${ }_{176}$ See Gruber, supra note 128, at 585.

177 See Thusi, supra note 135, at 229. 
historical conditions that inform sex work as well as localization to address the particular concerns of the relevant community. ${ }^{178}$

It is important to develop a framework that recognizes the realities of sex workers. This framework might include police manual guidelines and training specific to the treatment of sex workers; messaging and communications manuals and toolkits that educate stakeholders about how to talk about sex workers and advance a narrative that empowers them; partnerships, and community forums comprising police and sex workers to discuss concerns and problem-solving strategies; increased sensitivity in the public health research that pertains to sex workers in the language used to speak about sex workers and the inclusion of sex workers' clients in the discussions; and partnerships that ensure that police are educated about the human rights and constitutional protections that they are mandated to provide sex workers.

\section{CONCLUSION}

By adopting an intersectional lens to the question of whether sex work should be criminalized, this Article demonstrates how the production of a criminal law order that criminalizes any aspect of sex work may be more harmful to sex workers than sex work itself. The turn toward the carceral in the radical feminist literature to eventually abolish sex work uses the tools of oppression and social control (criminalization) in an attempt to empower the sex worker victim while simultaneously silencing her voice and stigmatizing her conduct.

The social harms of sex work advanced by radical feminists are in fact reproduced within the radical feminist literature itself; i.e., radical feminism is itself an exercise of patriarchy and subordination, especially as concerned with the experiences of sex workers of color. Why should the needs of the singular womankind, who is presumably a white middleclass womankind, be elevated above the needs of the working class, of color, and of poverty? Should feminists ask poor women to wait for utopia, ${ }^{179}$ a world with equal economic opportunity, when they face real economic challenges today? Are the harms of being unable to feed a child, or living in a country with high unemployment, not also real? Isn't sex work a way to mitigate against other real harms that they face? And,

${ }^{178}$ Activists have at times reinforced the discourses that police sex workers' bodies, for example in the public health context, while advocating for decriminalization. The law is viewed as the solution for sex worker issues, and the thrust of the debate focuses on criminalization. However, the law can be violent and discriminatory, especially towards disenfranchised women.

179 Catharine Mackinnon argues that "the abstract equality of liberalism permits most women does little more than does the substantive inequality of conservatism." Catharine A. MacKinnon, Feminism Unmodified: Discourses on Life and LaW 16 (1987). 
aren't individuals who face overlapping systems of oppressions always managing competing harms, or risks, and thus must simply choose the least harmful option and balance the risks on a day-to-day basis? Is it fair to say that these individuals cannot exercise any choices because we don't live in a perfect world?

Radical feminism often relies upon a discourse that disempowers sex workers and is consistent with discourses that focus on sex workers as public nuisances, immoral, and pathological. By suggesting that their work is categorically "wrong" or immoral and treating it as a vice to be eliminated, these scholars marginalize sex workers and reflect a continuity with patriarchal discourses that condemn sex work because it is a form of female sexuality that is inconsistent with dominant morality. To in turn suggest that these women were somehow incapable of making this choice, suffering from false consciousness, or otherwise less credible would seem to be an act of violence and subordination that the literature aims to address. Gayarti C. Spivak famously asked, "Can the subaltern speak? What must the elite do to watch out for the continuing construction of the subaltern?"180 I think the first step is for the elites, radical feminists in this context, to actually listen and consider the varied experiences of sex workers.

${ }^{180}$ Gayatri Chakravorty Spivak, Can the Subaltern Speak?, in MARXISM AND THE INTERPRETATION OF CULTURE. 271 (C. Nelson \& L. Grossberg eds., 1988). 
